\title{
Hatay yöresinde yetiştirilen 'Hicaznar' ve 'Katırbaşı' nar çeşitlerinin soğukta ve modifiye atmosferde muhafazası
}

Modified atmosphere packaging and cold storage of 'Hicaznar' and 'Katırbaş' pomegranate varieties grown in Hatay

\author{
Ahmet Erhan ÖZDEMiR ${ }^{1}$ (D), Tuğba ATABEY ${ }^{1}$ \\ ${ }^{1}$ Hatay Mustafa Kemal Üniversitesi, Ziraat Fakültesi, Bahçe Bitkileri Bölümü, Antakya-Hatay, Turkey.
}

MAKALE BILGISI / ARTICLE INFO

\section{Makale tarihçesi / Article history:}

DOI: $10.37908 /$ mkutbd.943311

Geliş tarihi /Received:26.05.2021

Kabul tarihi/Accepted:17.08.2021

\section{Keywords:}

Pomegranate, 'Hicaznar', 'Katırbaşı', MAP, storage, quality.

\footnotetext{
Corresponding author: A. Erhan Özdemir $\varangle:$ erhan@mku.edu.tr
}

\author{
ÖZET / A BSTRACT
}

Atıf / Citation: Özdemir AE, Atabey T (2021) Hatay yöresinde yetiştirilen ‘Hicaznar’ ve 'Katırbaşı’ nar çeşitlerinin soğukta ve
modifiye atmosferde muhafazası. MKU. Tar. Bil. Derg. 26(3) : 617-634. DOI: 10.37908/mkutbd.943311

\section{Giriş}

Nar (Punica granatum L.) dünyanın birçok tropikal ve subtropikal bölgesinde özellikle Akdeniz ülkelerinde yetiştirilen önemli bir meyve türüdür (Artes ve ark., 2000; Nanda ve ark., 2001). Genellikle taze olarak tüketilmekle birlikte boya, ilaç, konserve, marmelat, meyve suyu, nar konsantresi, nar ekşisi, nar pekmezi, sirke ve hayvan yemi üretimi gibi çok çeşitli tarıma dayalı sanayide nardan faydalanılmaktadır. Narın çiçeklerinden bitkisel yağ elde edilmektedir (Kingsly ve ark., 2006).
Günümüzde nar meyvesi, içerdiği insan sağlığına yararlı bileşikler ve dolayısıyla insan sağlığı üzerindeki olumlu etkileri sebebiyle, fonksiyonel gıdalar sınıfında bulunmaktadır (Rosenblat ve ark., 2006).

1990 'da 50000 ton olan nar üretimimiz, 2020 yllı itibariyle 600021 tona ulaşmıştır (Anonim, 2021a). 2020 yılı verilerine göre; Türkiye' de en fazla nar yetiştirilen il Antalya (141044 ton) olup, bunu sırasıyla Mersin (101676 ton), Adana (78483 ton), Muğla (75995 ton), Denizli (44233 ton) ve Hatay (27827 ton) izlemektedir. Hatay ilinde önemli ilçeler sırasıyla Kırıkhan (7468 ton), 
Hassa (6280 ton), Antakya (4115 ton), Arsuz (2835 ton), Yayladağı (1560 ton) ve Altınözü (1352 ton)'dür (Anonim, 2021a). 2000 yılında 3120 ton olan taze nar ihracatı, 2020 yılında 191971 tona ulaşmıştır (Anonim, 2021b). Türkiye'nin yanı sıra dünyada nar dış satımı yapan ülkeler Hindistan, ABD, İspanya, İsrail, Mısır ve İran'dır (Sezen, 2021).

Modifiye Atmosferde Paketlemenin (MAP) amacl, ortam oksijenin azaltılmasıyla ürünü çevreleyen hava bileşiminin değiştirilmesidir. Böylece; ürünün solunumunu yavaşlatmak, bozulma tepkimelerini azaltmak, bozulmaları geciktirerek, ürün güvenliğini ve kalitesini koruyarak, ürünün muhafaza ve raf ömrü uzatılmaktadır (Farber ve ark., 2003). Dahası, duyusal ve ticari kalitenin korunması sağlanmaktadır.

Nar meyvelerinin muhafazasını çeşit, derim öncesi faktörler (ekolojik koşullar, kültürel bakım işleri, hastalık ve zararlılarla mücadele, besleme, derim olum zamanının belirlenmesi vs.) derimin yapılış şekli, ön soğutma, sıcaklık ve oransal nem gibi depolama koşulları ve kullanılan MAP ambalajının su ve gaz geçirgenlik özellikleri etkilemektedir (Gil ve ark., 2000; Heshi ve ark., 2001).

Nar meyveleri çeşide bağlı olarak kızıldan kırmızıya kabuk rengi olan mumsu parlak bir yüzeye sahiptir. Meyveler genellikle tam olgunlaştığı zaman derilir ve klimakterik bir solunum eğrisi göstermediğinden düşük solunum hızına sahiptir (Crisosto ve ark. 1996). Nar meyvelerinde depolama sıcaklığı çeşide göre değişmektedir. Genellikle tavsiye edilen depolama sıcaklığı $0-10^{\circ} \mathrm{C}$ ve raf ömrü ise 1-2 hafta arasındadır (Nanda ve ark., 2001). Nar meyveleri, $5{ }^{\circ} \mathrm{C}^{\prime}$ nin altındaki sıcaklıklarda 2 aydan fazla depolandığında "üşüme zararı" görülmektedir. Narlarda üşüme zararının belirtileri; kabukta kahverengi renk oluşumu, kabuk yüzeyinde çukurların oluşması, tane renginin solması, taneleri çevreleyen beyaz kısmın kahverengileşmesi ve mantarsal bozulmaların artmasıdır (Artes ve ark., 2000). Depolama sırasında narlarda su kaybının artmasıyla meyve kabuğunda sertleşme, kahverengimsi renk ve tanelerde kahverengileşme görülmektedir. Nar kabuğu üzerinde su buharının hareketine izin veren lentiseller olduğundan nar meyveleri su kaybına oldukça duyarlıdır (Kader ve ark., 1984; Gil ve ark., 1996; Nanda ve ark., 2001). 'Hicaznar' nar çeşidinin $6{ }^{\circ} \mathrm{C}$ sıcaklık ve \%90 oransal nemde depolanması gerektiği birçok araştırıcı tarafından bildirilmiştir (Şen ve ark., 2013; Selçuk ve Erkan, 2014; Karaşahin ve ark., 2017; Aksoy, 2019; Çandır ve ark., 2018; 2019).

Gözlekçi ve ark. (2005) tarafından yapılan bir çalışmada, MAP ambalaj materyalinin 'Hicaznar' nar çeşidinin, depo ömrünü uzatmadaki etkileri araştırılmış ve meyveler 6
${ }^{\circ} \mathrm{C}^{\prime}$ de ve \%90-92 oransal nemde depolanmıştır. Çalışmanın sonuçlarına göre, MAP'ın 'Hicaznar' nar meyvelerinin depo ömrünü en az kalite kaybıyla uzattığı belirlenmiştir. Adana koşullarında yetiştirilen, MAP (kalınlık $8 \mu$ ) ile paketlenen 'Hicaznar' nar çeşidinin 6 ay soğukta muhafazası ve 15 gün raf ömrü incelenmiş ve 'Hicaznar' nar çeşidinde, ambalajlamanın kontrole göre daha iyi muhafaza olanağı sağladığı ve modifiye atmosferde paketlenen meyvelerin 2-3 ay muhafaza edilebileceği saptanmıştır (Bayram ve ark., 2010).

Oğuz ve ark. (2014) tarafından yürütülen bir çalışmada, Adıyaman ilinin farklı lokasyonlarında yetiştirilen 'Katırbaşı' nar çeşidine ait meyvelerin depolama süresince pomolojik, fiziksel ve biyokimyasal özelliklerindeki değişimler belirlenmiş olup, meyveler MAP ambalajda $6{ }^{\circ} \mathrm{C}$ sıcaklıkta ve $\% 90$ oransal nemde 4 ay süreyle muhafazaya alınmış ve farklı lokasyonlarda yetiştirilen 'Katırbaşı' nar meyvelerinin 4 ay süreyle başarıyla depolanabileceği saptanmıştır. Selçuk ve Erkan (2014) yaptıkları bir çalışmada, MAP ambalajın 'Hicaznar' nar çeşidi meyvelerinde $6{ }^{\circ} \mathrm{C}$ ' de $90-95 \%$ oransal nemde 120 gün muhafaza sırasında ağırlık kayıplarının ve çürük meyve miktarının azaltılmasında, görsel kalitenin ve meyve kabuk renginin korunmasında oldukça etkili olduğunu saptamışlardır.

Daha önce Adıyaman ilinin farklı lokasyonlarında yetiştirilen 'Katırbaşı' nar çeşidiyle $6{ }^{\circ} \mathrm{C}$ sıcaklıkta ve \%90 oransal nemde 4 ay süreyle yapılan çalışmadan farklı olarak, bu çalışmada, Adıyaman ili ekolojisinden farklı olan Hatay ili koşullarında yetiştirilen 'Hicaznar' ve 'Katırbaşı' nar çeşitlerinde MAP ambalajın soğukta muhafaza sırasında 6 ay süreyle kaliteye etkisinin belirlenmesi amaçlanmıştır.

\section{MATERYAL ve YÖNTEM}

\section{Materyal}

Bu çalışmada materyal olarak, Hatay Mustafa Kemal Üniversitesi Tarımsal Araştırma ve Uygulama Merkezi Selam Çiftliğinde 'Hicaznar' nar çeşidi üretim parselinden sağlanan $5 \times 5 \mathrm{~m}$ aralık ve mesafelerle dikilmiş, 9 yaşlı 'Hicaznar' nar çeşidi ve Hatay ili Altınözü ilçesinde üretici bahçesinden temin edilen $6 \times 6 \mathrm{~m}$ aralık ve mesafelerle dikilmiş, 20 yaşı 'Katırbaşı' nar çeşidi meyveleri kullanılmıştır.

'Hicaznar' çeşidinin meyve ağırlığı ortalama $350 \mathrm{~g}$, meyve eni ortalama $91 \mathrm{~mm}$ 'dir. Meyve kabuk rengi sarı zemin üzerine \%95 kırmızıdır. Daneler koyu kırmızı renkte ve 100 tanesinin ağırlığı ortalama 26.10 g'dır. Asitlik ortalama \%1.90 olup ekşiye yakın mayhoştur. Çekirdekleri serttir. Akdeniz bölgesinin sahil ve geçit yörelerinde iyi yetişmektedir (Onur, 1988). 'Katırbaşı' nar 
çeşidi: 330-850 g arasında değişen iri meyveli, kabuk rengi sarı zemin üzerinde kırmızı (\%30) yanaklı, tadı mayhoş, kabuk kalınlığı ince, meyve suyu usare miktarı yüksek (\%40-45), iri taneli ve dane rengi koyu pembe, kolay tanelenebilen, dane randımanı yüksek, asitlik oranı \%1.30 civarında, çekirdek sertliği orta, yüksek ve verimli bir çeşittir (Yılmaz, 2007; Çandır ve ark., 2020).

Çalışmada materyal olarak nar meyveleri için geliştirilmiş, ülkemizde yaygın olarak kullanılan 12 kg'lık Life Pack $^{\circledR} /$ Aypek $^{\circledR}$ (Patent No.: 2007 45625, Aypek Ambalaj San. Tic. ve Paz. Ltd. Şti., Bursa) MAP ambalaj kullanılmıştır.

\section{Yöntem}

Çeşide özgü renk ve iriliğini aldığı, titre edilebilir asitlik kapsamı (TEA)<\%1.85 ve suda çözünebilir toplam kuru madde (SÇKM)'si >\%17 olduğu (Crisosto ve ark. 1996; Çandır ve ark., 2018; 2019) optimal olgunluk döneminde derilen 'Hicaznar' ve 'Katırbaşı' nar çeşidi meyvelerinde, derimden sonra benzer irilik ve boyda olan sağlam meyveler seçilmiş ve plastik kasalara konarak hava ile 24 saat süreyle önsoğutmaya alınmış ve önsoğutma sonrası MAP ambalajlara konarak $6 \pm 0,5{ }^{\circ} \mathrm{C}^{\prime}$ de ve $\% 90 \pm 5$ oransal nemde 6 ay süreyle depolanmıştır. Meyveler plastik kasalarda 12 kg'lık MAP ambalajlar içerisine her yinelemede $12 \mathrm{~kg}$ olacak şekilde 3 yinelemeli olarak yerleştirilmiş ve ambalajın ağzı klipslerle bağlanmıştır. Kontrol meyveleri ambalajlanmaksızın plastik kasalar içerisinde depolanmıştır. Ayrıca, raf ömrü için her ay depolamadan sonra meyveler $20 \pm 1{ }^{\circ} \mathrm{C}$ sıcaklık ve $\% 70 \pm 5$ oransal nem koşullarında 7 gün bekletilmiştir. Çalışma, muhafaza süresince ayda bir ve raf ömrü sırasında 7 . gün sonunda alınan meyve örneklerinde her çeşit için 3 yinelemeli ve her yinelemede 5 meyve kullanılarak yürütülmüştür.

Ambalajlar içindeki $\mathrm{CO} 2$ ve $\mathrm{O} 2$ konsantrasyonlarının belirlenmesi (\%): MAP ambalajları içindeki $\mathrm{CO} 2$ ve $\mathrm{O} 2 \mathrm{gaz}$ konsantrasyonları taşınabilir gaz analiz cihazı (PBIDansensor America Inc., NJ, ABD) ile yüzde olarak ölçülmüştür.

Ağılık kayıpları (\%): Her çeşit için $15^{\prime}$ er adet meyve tek tek numaralandırılmış ve her ay 0.01 g'a duyarlı hassas teraziyle (Ohaus Adventurer, ABD) tartılarak başlangıç ağırlığından son ağırlığı çıkarılıp yüzde olarak hesaplanmıştır.

Görünüş: 1-5 skalasına göre, meyve rengi, şekil ve biçim, parlaklık, üşüme zararlarının şiddeti vb. kriterlere göre (1: çok kötü, 2: kötü, 3: orta, 4: iyi, 5: çok iyi) değerlendirilmiştir. Skaladaki "3" pazarlanabilir kalitede olma sınırını oluşturmaktadır.

Mantarsal ve fizyolojik nedenlerle bozulan meyve miktarı (\%): Depo koşullarında muhafaza edilen meyvelerden her ay alınan örnekler teker teker incelenmiş, muhafaza sırasında ortaya çıkan fizyolojik bozulmalar ve mantarsal nedenli çürümeler belirlenmiş ve çürüme oranları \% olarak saptanmıştır. Ayrıca, fizyolojik bozulma şiddetinin belirlenmesinde $1-5$ skalası kullanılmıştır. Bu skalada Defilippi ve ark. (2006) ile Çandır ve ark. (2018; 2019)'un kullandığı skalalar revize edilerek kullanılmıştır. Kullandığımız skalada 1) Sağlıklı, bozulma yok; 2) Hafif, meyve kabuk yüzeyinde $\% 10^{\prime}$ dan az bozulma; 3) Orta, meyve kabuk yüzeyinin \%11-25'i zararlanmış; 4) Şiddetli, meyve kabuk yüzeyinin \%2650'si zararlanmış ve 5) Çok şiddetli, meyve kabuk yüzeyinin $\% 50$ 'den fazlası zararlanmış olarak değerlendirilmiş ve puanı 3 ve $3^{\prime}$ ün altında olanlar pazarlanabilir durumda olarak kabul edilmiştir.

Tat: Meyvelerin tadı 10 kişiden oluşan bir panelist grup tarafından başlangıçtaki tat değerleri dikkate alınarak 19 hedonik skalaya göre değerlendirilmiştir. Bu skalada 9 en iyi ve 1 en düşük değer olmuştur. Skaladaki " 5 " pazarlanabilir kalitede olma sınırını oluşturmaktadır.

Meyve kabuk ve tane rengi: Meyve kabuk rengi için; L* ve ${ }^{\circ}$ değerleri; ağırlık kayıpları için her ay depodan dışarı çıkarılıp tekrar depoya konan aynı meyvelerde C.I.E. L*a*b*'ye göre Minolta CR-300 Chromometer renk ölçüm cihazı (Konica Minolta, Osaka, Japonya) ile meyvelerin iki tarafından daha önceden işaretlenen yerlerden her seferinde okuma yapılmıştır (McGuire, 1992). Tane rengi için ise her analizde kesilip parçalara ayrılan meyvelerde, tanelenmeden önce okuma yapılmıştır.

Meyve suyu (usare) miktarı (\%): Meyve suları çıkarılmış ve dane ağırlığına göre meyve suyu miktarı yüzde olarak belirtilmiştir.

Suda çözünebilir toplam kuru madde (SÇKM) miktarı (\%): Elde edilen meyve suyundan el refraktometresi (Atago ATC-1E Model, Atago Co. Ltd., Tokyo, Japonya) ile yüzde olarak saptanmıştır.

Titre edilebilir asit (TEA) miktarı (\%): Potansiyometrik yöntem (Sadler, 1994) ile ölçülmüş olup, $5 \mathrm{ml}$ meyve suyuna $95 \mathrm{ml}$ saf su eklenmiş, pH metrede 8,1 değeri okunana kadar $0,1 \mathrm{~N} \mathrm{NaOH}$ çözeltisi ile titre edilmiş (Brand titrette, Almanya) ve sonuçlar sitrik asit cinsinden yüzde olarak "g sitrik asit / $100 \mathrm{ml}$ meyve suyu" cinsinden hesaplanmıştır.

Meyve suyu $\mathrm{pH}$ değeri: Elde edilen meyve suyundan dijital pH metre (Hanna Instruments, HI 2211 pH/ORP meter, $A B D$ ) ile ölçülmüştür.

\section{Deneme deseni ve değerlendirme}

Araştırma "Faktöriyel Düzende Tesadüf Parselleri" deneme desenine göre kurulmuş olup, elde edilen verilerin istatistiksel değerlendirme SAS programı (SAS 
Version V.9.4, SAS Institute Cary, N.C.) kullanılarak yapılmıştır. Çalışma faktöriyel düzende kurulmuş olmakla birlikte, $F$ testi sonunda önemli bulunan varyasyon kaynaklarına ait ortalamaların karşılaştırılması Tukey testi $(P<0.05)$ ile yapılmış ve çizelgelerde sonuçlar verilmiştir.

\section{BULGULAR ve TARTIŞMA}

'Katırbaşı' nar çeşidinin konulduğu depoya fare girmesi nedeniyle meyvelere farelerin yaptığı zarardan dolayı muhafazanın 6. ayı analizleri bu çeşitte yapılamamıştır.

\section{Ambalaj içindeki $\mathrm{CO} 2$ ve 02 konsantrasyonları}

Soğukta muhafaza sırasında MAP ambalajlarda $\mathrm{O} 2$ konsantrasyonu azalırken, $\mathrm{CO} 2$ konsantrasyonu artmıştır. 'Her iki çeşitte de MAP uygulamasında $\mathrm{O} 2$ konsantrasyonunda düşüş ve $\mathrm{CO} 2$ konsantrasyonunda artış görülmüştür. Muhafaza periyodunun başlangıcında Hicaznar' ve 'Katırbaşı' nar çeşidi meyvelerinin MAP uygulamasında $\mathrm{O} 2$ ve $\mathrm{CO} 2$ konsantrasyonları sırasıyla \%20.90 ve \%0.00 iken, Hicaznar' nar çeşidinde soğukta muhafaza sırasında 6 . ayda sırasıyla $\% 15.83$ ile $\% 7.63$ ve 'Katırbaşı' nar çeşidinde 5. ayda sırasıyla \%15.38 ile \%7.36 değerlerine ulaşarak denge atmosferi sağlanmıştır. 'Canernar-1' ve 'Hicaznar' nar çeşitlerinde yapılan MAP'de muhafaza çalışmalarının sonuçlarına göre, 120-210 günlük muhafaza periyodu sonunda Xtend $^{\circledR}$ MAP ambalajda 02 konsantrasyonun \%13.5017.60 ve $\mathrm{CO} 2$ konsantrasyonun $\% 4.40-8.10$ arasında değiştiği belirlenmiş (Selçuk ve Erkan, 2013; 2015) ve MAP ambajındaki bu konsantrasyonlar, ağırlık kaybı ve çürüme en aza indirmek ve nar çeşitlerinin genel görsel kalitesini korumak için önerilmiştir (Selçuk ve Erkan, 2014; 2015). Gözlekçi ve ark. (2005) tarafından 'Hicaznar' çeşidinde yapılan bir çalışmada, Xtend ${ }^{\circledR}$ MAP ambalajda $6{ }^{\circ} \mathrm{C}^{\prime}$ de ve $\% 90-92$ oransal nemde 45 gün depolama sonucunda $\mathrm{O} 2$ ve $\mathrm{CO} 2$ konsantrasyonunun $\% 16.50$ ve $\% 5.80$ olarak belirlenmiştir. Bolel ve ark. (2019) aynı nar çeşidinde MAP içi $\mathrm{O} 2$ ve $\mathrm{CO} 2$ konsantrasyonlarının $6{ }^{\circ} \mathrm{C}$ ve $\% 90 \pm 5$ oransal nemde depolama (5 ay) süresince bulgularımıza benzer bir değişim gösterdiğini bildirmişlerdir.

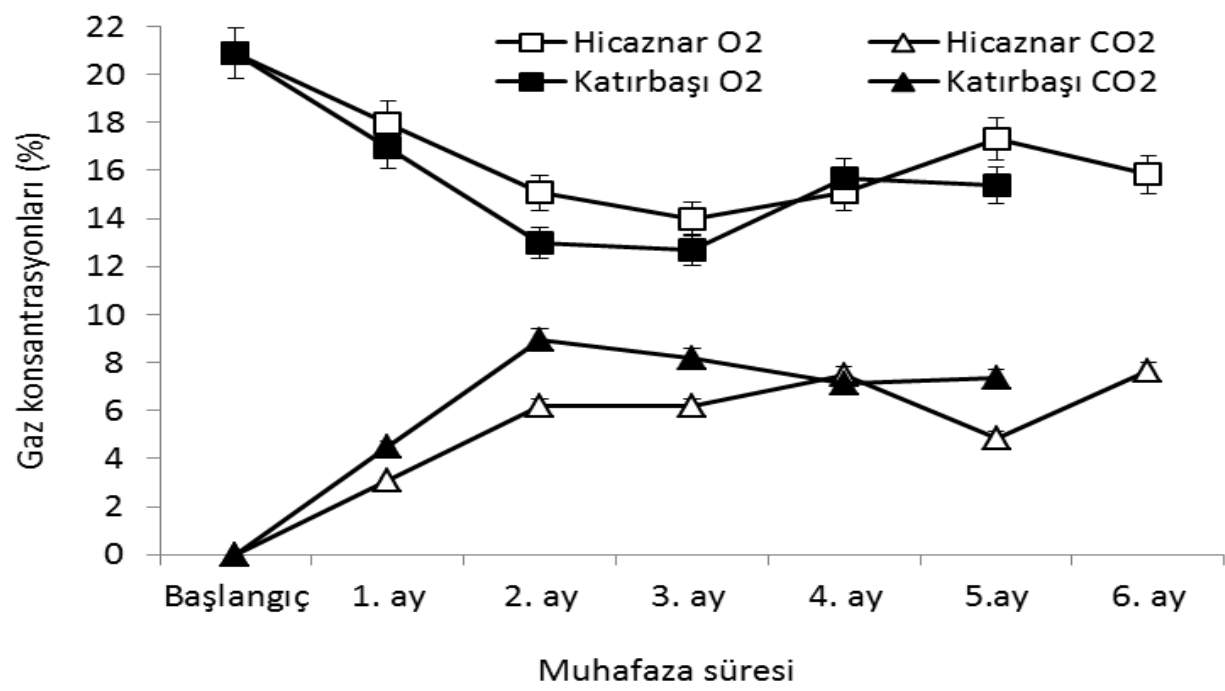

Şekil 1. 'Hicaznar' ve 'Katırbaşı' nar çeşidi meyvelerinin muhafaza süresince MAP ambalajı içindeki O2 ve CO2 konsantrasyonlarındaki değişimler.

Figure 1. Changes in $\mathrm{O} 2$ and $\mathrm{CO} 2$ concentrations in the MAP package of 'Hicaznar' and 'Katırbaşı' pomegranate cultivar fruits during storage.

\section{Ağırlık kayıpları}

'Hicaznar' nar çeşidinde muhafaza süresi uzadıkça ağırlık kaybı düzeyi artmış ve altı ayın sonunda ortalama \%14.11'e ulaşmıştır. Ağılık kaybı MAP ambalajda ortalama \%4.54 olurken, kontrolde \%13.52 olmuştur. Raf ömrü süresi uzadıkça ağırlık kaybı artış ve azalışlar göstermiş ve ortalama \%1.16 ile 4.66 arasında olmuştur. Raf ömrü sırasında ağırık kaybı MAP ambalajda (ortalama \%2.67) kontrolden (\%1.94) daha fazla olmuştur (Çizelge 1). 'Katırbaşı' nar çeşidinde muhafaza süresi uzadıkça ağırlık kaybı artmış ve 5 ayın sonunda ortalama \%13.15'e ulaşmıştır. Ağırlık kaybı MAP ambalajda ortalama \%4.61 olurken, kontrolde \%10.78 olmuştur. Muhafaza süresine bağlı olarak ilerleyen raf ömrü süreçlerinde ağırlık kaybı artış azalışlar göstermiş ve ortalama \%1.91 ile 6.35 arasında olmuştur. Raf ömrü sırasında ağırlık kaybı MAP ambalajda (ortalama \%3.23) kontrolden (\%2.94) daha fazla olmuştur (Çizelge 2). Şen 
ve ark. (2013) tarafından test edilen MAP ambalajlarının su buharı geçirgenliğine bağlı olarak MAP ambalaj türleri arasında ağırlık kaybında önemli farklılıklar olabileceği bildirilmiştir. Altı ay soğukta muhafazada edilen ve 20 ${ }^{\circ} \mathrm{C}$ 'de 7 gün bekletilen 'Hicaznar' ve 'Katırbaşı' nar çeşitlerinde MAP ambalajdaki meyvelerde ağırlık kaybı oranı nar meyvesi için Elyatem ve Kader (1984) tarafından belirtilen sınır değerinin (\%5) altında kamıştır. Porat ve ark. (2016) tarafından yapılan çalışmada MAP ambalajında $7{ }^{\circ} \mathrm{C}$ 'de 16 hafta depolanan ve $20^{\circ} \mathrm{C}^{\prime}$ de 7 gün bekletilen 'Wonderful' çeşidi nar meyvelerinde ağırlık kaybı oranı \%2'nin altında kalırken, açıkta depolanan meyvelerde 8 . haftada ağırlık kaybının \%6.40 oranına ulaşmasıyla buruşmanın başladığı gözlemlenmiştir. $\mathrm{Bu}$ oranlar bulgularımızla karşılaştırıldığında çok daha düşük bulunmuştur. Yapılan bir çalışmada, $6{ }^{\circ} \mathrm{C}^{\prime}$ de 4-6 aylık soğukta muhafaza periyodu sonunda MAP ambalajlarda ve açıkta depolanan nar meyvelerinde ağırlık kaybı oranı sırasıyla \%1.30-7.70 ve \%11.77-26.57 arasında değişmiştir (Selçuk ve Erkan, 2013; 2014; 2015; 2016). Bulgularımıza benzer olarak, Bolel ve ark. (2019) MAP içerisinde $6{ }^{\circ} \mathrm{C}$ ve $\% 90 \pm 5$ oransal nemde 5 ay süre ile muhafaza edilen 'Hicaznar' nar çeşidi meyvelerinde muhafaza sonunda ağırlık kaybı \%4.23 olmuştur. Bulgularımızdan farklı olarak, Selçuk ve Erkan (2014; 2015; 2016)'ın yaptıkları çalışmalarda, soğukta muhafazadan sonra raf ömrü periyodunda ise MAP ambalajda \%1.43-8.45 ve kontrolde \%11.77-30.43 oranında ağırlık kaybı meydana gelmiştir.

\section{Görünüş ve tat değerlendirmesi}

'Hicaznar' nar çeşidinde muhafaza süresi uzadıkça 1-5 skalasına göre görünüş puanları düşmüş, 4. ayda ortalama 4.07 olmuş ve 5 ayın 2.82'ye düşerek tüketici kabul edilebilirliğini kaybetmiş ve 6 . ayda da 2.31 'e düşmüştür. Görünüş puanları MAP ambalajda (ortalama 4.65) kontrolden (3.45) daha yüksek olmuştur. Raf ömrü süresi uzadıkça görünüş puanları düşmüş, 4. ayda ortalama 4.01 olmuş ve 5 ayın 2.53'e düşerek tüketici kabul edilebilirliğini kaybetmiş ve 6 . ayda da 2.10'a düşmüştür. Raf ömrü sırasında görünüş puanları MAP ambalajda (ortalama 4.52) kontrolden (3.51) daha yüksek olmuştur. MAP ambalajda görünüş puanları 6 ay sonunda bile kabul edilebilir sınırın ( $>3$ ) altına hiç düşmezken, kontrol meyveleri 4. aydan sonra tüketici kabul edilebilirliğini kaybetmişlerdir (Çizelge 1). 'Katırbaşı' nar çeşidinde muhafaza süresi uzadıkça 1-5 skalasına göre görünüş puanları düşmüş, 3. ayda ortalama 3.50 olmuş ve 4 ayın 2.07'ye düşerek tüketici kabul edilebilirliğini kaybetmiş ve 5 . ayda da $1.75^{\prime}$ e düşmüştür. Görünüş puanları MAP ambalajda (ortalama 4.19) kontrolden (3.14) daha yüksek olmuştur. Raf ömrü süresi uzadıkça görünüş puanları düşmüş, 3 . ayda ortalama 3.02 olmuş ve 4 ayın 1.37'ye düşerek tüketici kabul edilebilirliğini kaybetmiş ve 5. ayda da 1.20'ye düşmüştür. Raf ömrü sırasında görünüş puanları MAP ambalajda (ortalama 3.64) kontrolden (2.78) daha yüksek olmuştur. MAP ambalajda görünüş puanları 6 ayda ve kontrol meyveleri ise 3 . ayda tüketici kabul edilebilirliğini kaybetmişlerdir (Çizelge 2). Bulgularımıza benzer olarak, nar meyvelerinin muhafazası sırasında muhafaza süresinin uzamasına paralel olarak narların dış görünüşlerinde su kaybı, çürümeler, üşüme zararı, yüzeysel kabuk yanıklığı nedeniyle kalite kayıpları ortaya çıktığı değişik araştırıcılar tarafından bildirilmiştir (D'Aquino ve ark., 2010; Selçuk ve Erkan, 2014; 2015; 2016; Çandır ve ark., 2018; 2019). Bulgularımıza benzer olarak, D'Aquino ve ark. (2010) tarafından yapılan bir çalışmada, 12 hafta muhafaza edilen 'Primosole' nar çeşidinde MAP film ile sarılan meyvelerinin iyi durumda olduğu ve kontrol meyvelerinin de pazarlanabilir limitler içerisinde kaldığı bildirilmiştir. Benzer şekilde, Selçuk ve Erkan (2014) tarafından 'Hicaznar' nar çeşidiyle yapılan bir çalışmada $6{ }^{\circ} \mathrm{C}$ 'de depolanan ve $20^{\circ} \mathrm{C}$ 'de 3 gün bekletilen, kontrol meyvelerinin 80 gün ve MAP ambalajda depolanan meyvelerin 100 gün pazarlanabilir kalite sınırlarında kaldıklarını ve 120 . günde her iki grup meyvelerin pazarlanamaz hale geldiklerini bildirmişlerdir. Bolel ve ark. (2019) MAP içerisinde muhafaza edilen 'Hicaznar' nar çeşidi meyvelerinde 5 ay muhafaza sonunda 4.83 puan ile pazarlanabilir puanı olan 5'in altıda kaldığını belirtmişlerdir. 'Hicaznar' nar çeşidinde 1-9 skalasına göre başlangıçta ortalama 9.00 olan tat puanları muhafaza süresi uzadıkça azalışlar göstermiş ve 6 ayın sonunda 6.69'a düşmüştür. Muhafaza sırasında tat puanlarında ambalajlar arasındaki farklar istatistiksel olarak önemsiz bulunmuştur. Raf ömrü sırasında da başlangıçta ortalama 9.00 olan tat puanları raf ömrü süresi uzadıkça azalışlar göstermiş ve 6 ayın sonunda 6.98'e düşmüştür. Ancak, raf ömrü sırasında tat puanlarında ambalajlar arasındaki farklar istatistiksel olarak benzer bulunmuştur. Bununla birlikte, muhafaza ve raf ömrü sırasında tat puanları 6 ay sonunda bile kabul edilebilir değerlerin (>5.00) üzerinde olmuştur (Çizelge 1). 
Çizelge 1. MAP ambalajlamanın $6^{\circ} \mathrm{C}^{\prime}$ de 6 ay muhafaza edilen 'Hicaznar' nar çeşidinde ağırlık kaybı, görünüş, tat, usare miktarı, mantarsal ve fizyolojik bozulmalar ve fizyolojik bozulma şiddeti üzerine etkileri

Table 1. Effects of MAP packaging on weight loss, appearance, taste, juice content, incidence of fungal decay and physiological disorder and physiological disorder severity in 'Hicaznar' pomegranate cultivar during 6 months of storage at $6^{\circ} \mathrm{C}$

\begin{tabular}{|c|c|c|c|c|c|c|c|}
\hline Muhafaza & $\begin{array}{c}\text { Ağırlık kaybı } \\
(\%)\end{array}$ & $\begin{array}{c}\text { Görünüş } \\
(1-5)\end{array}$ & $\begin{array}{l}\text { Tat } \\
(1-9)\end{array}$ & $\begin{array}{c}\text { Usare } \\
\text { miktarı (\%) }\end{array}$ & $\begin{array}{c}\text { Mantarsal } \\
\text { bozulma (\%) }\end{array}$ & $\begin{array}{c}\text { Fizyolojik } \\
\text { bozulma (\%) }\end{array}$ & $\begin{array}{c}\text { Fizyolojik } \\
\text { bozulma şiddeti } \\
(1-5)\end{array}$ \\
\hline \multicolumn{8}{|c|}{ Soğukta muhafaza ambalaj } \\
\hline Kontrol & $13.52 \mathrm{a}$ & $3.45 b$ & 7.24 & $43.44 \mathrm{a}$ & $0.37 \mathrm{~b}$ & 6.30 & 1.05 \\
\hline MAP & $4.54 \mathrm{~b}$ & $4.65 \mathrm{a}$ & 7.17 & $41.09 \mathrm{~b}$ & $5.56 \mathrm{a}$ & 7.04 & 1.07 \\
\hline D\%5 (ambalaj) & 0.24 & 0.15 & Ö.D. & 1.89 & 3.59 & Ö.D. & Ö.D. \\
\hline \multicolumn{8}{|c|}{ Soğukta muhafaza süresi (ay) } \\
\hline 0 & --- & $5.00 \mathrm{a}$ & $9.00 \mathrm{a}$ & $47.13 \mathrm{a}$ & --- & --- & $1.00 \mathrm{~b}$ \\
\hline 1 & $3.23 \mathrm{f}$ & $5.00 \mathrm{a}$ & $8.72 \mathrm{a}$ & $47.95 \mathrm{a}$ & $0.00 \mathrm{~b}$ & $0.00 \mathrm{~b}$ & $1.00 \mathrm{~b}$ \\
\hline 2 & $5.40 \mathrm{e}$ & $4.93 \mathrm{a}$ & $7.25 b$ & $40.46 \mathrm{bc}$ & $0.00 \mathrm{~b}$ & $0.00 \mathrm{~b}$ & $1.00 \mathrm{~b}$ \\
\hline 3 & $7.06 \mathrm{~d}$ & $4.22 \mathrm{~b}$ & $6.42 b c$ & $42.49 \mathrm{ab}$ & $0.00 \mathrm{~b}$ & $0.00 \mathrm{~b}$ & $1.00 \mathrm{~b}$ \\
\hline 4 & $11.68 \mathrm{c}$ & $4.07 \mathrm{c}$ & $6.33 \mathrm{bc}$ & $43.04 a b$ & $0.00 \mathrm{~b}$ & $0.00 \mathrm{~b}$ & $1.00 \mathrm{~b}$ \\
\hline 5 & $12.68 \mathrm{~b}$ & $2.82 \mathrm{~d}$ & $6.03 c$ & $39.25 \mathrm{bc}$ & $10.00 \mathrm{a}$ & $21.11 \mathrm{a}$ & $1.22 \mathrm{a}$ \\
\hline 6 & $14.11 \mathrm{a}$ & $2.31 \mathrm{e}$ & $6.69 \mathrm{bc}$ & $35.52 \mathrm{c}$ & $7.78 a b$ & $18.89 \mathrm{a}$ & $1.20 \mathrm{a}$ \\
\hline $\mathrm{D}_{\% 5 \text { (muhafaza) }}$ & 0.46 & 0.43 & 1.12 & 5.47 & 9.30 & 6.65 & 0.05 \\
\hline \multicolumn{8}{|l|}{ Raf ömrü ambalaj } \\
\hline Kontrol (Control) & $1.94 \mathrm{~b}$ & $3.51 \mathrm{~b}$ & 8.07 & 43.77 & 2.22 & $8.10 \mathrm{a}$ & 1.04 \\
\hline MAP & $2.67 \mathrm{a}$ & $4.52 \mathrm{a}$ & 8.07 & 43.75 & 1.27 & $3.81 \mathrm{~b}$ & 1.02 \\
\hline $\mathrm{D}_{\% 5 \text { (ambalaj) }}$ & 0.27 & 0.17 & Ö.D. & Ö.D. & Ö.D. & 3.29 & Ö.D. \\
\hline \multicolumn{8}{|c|}{ Raf ömrü süresi (ay + gün) } \\
\hline $0+7$ & $4.66 \mathrm{a}$ & $5.00 \mathrm{a}$ & $9.00 \mathrm{a}$ & $54.86 \mathrm{a}$ & $0.00 \mathrm{~b}$ & $0.00 \mathrm{c}$ & 1.00 \\
\hline $1+7$ & $2.88 \mathrm{~b}$ & $4.97 \mathrm{a}$ & $8.50 \mathrm{ab}$ & $43.17 \mathrm{bc}$ & $0.00 \mathrm{~b}$ & $0.00 \mathrm{c}$ & 1.00 \\
\hline $2+7$ & $1.52 \mathrm{de}$ & $4.93 \mathrm{a}$ & $8.42 \mathrm{abc}$ & $43.50 \mathrm{bc}$ & $1.11 \mathrm{~b}$ & $0.00 \mathrm{c}$ & 1.00 \\
\hline $3+7$ & $1.16 \mathrm{e}$ & $4.57 \mathrm{a}$ & $8.08 \mathrm{bc}$ & $43.31 \mathrm{bc}$ & $0.00 \mathrm{~b}$ & $0.00 \mathrm{c}$ & 1.00 \\
\hline $4+7$ & $1.24 \mathrm{e}$ & $4.01 \mathrm{~b}$ & $7.69 \mathrm{~cd}$ & $45.72 \mathrm{~b}$ & $0.00 \mathrm{~b}$ & $8.33 b c$ & 1.04 \\
\hline $5+7$ & $2.08 \mathrm{~cd}$ & $2.53 c$ & $7.82 b c$ & $39.01 b c$ & $0.00 \mathrm{~b}$ & $18.89 a$ & 1.09 \\
\hline $6+7$ & $2.60 \mathrm{bc}$ & $2.10 \mathrm{c}$ & $6.98 \mathrm{~d}$ & $36.75 \mathrm{c}$ & $11.11 \mathrm{a}$ & $14.45 a b$ & 1.10 \\
\hline $\mathrm{D}_{\% 5 \text { (raf ömrü) }}$ & 0.62 & 0.50 & 0.78 & 6.96 & 6.35 & 8.53 & Ö.D. \\
\hline
\end{tabular}

Ö.D.: Önemli değil.

'Katırbaşı' nar çeşidinde 1-9 skalasına göre başlangıçta ortalama 9.00 olan tat puanları muhafaza süresi uzadıkça azalışlar göstermiş ve 5 ayın sonunda $5.88^{\prime}$ e düşmüştür. Muhafaza sırasında tat puanlarında ambalajlar arasındaki farklar istatistiksel olarak benzer bulunmuştur. Raf ömrü sırasında da başlangıçta ortalama 9.00 olan tat puanları raf ömrü süresi uzadıkça azalışlar göstermiş ve 6 ayın sonunda 5.17’ye düşmüştür.
Ancak, raf ömrü sırasında tat puanlarında ambalajlar arasındaki farklar istatistiksel olarak benzer bulunmuştur. Bununla birlikte, muhafaza ve raf ömrü sırasında tat puanları 6 ay sonunda bile kabul edilebilir değerlerin (>5.00) altına düşmemiştir (Çizelge 2) MAP ambalajın tat ve dış görünüş bakımından duyusal kaliteyi korumada daha başarılı olduğu bildirilmiştir (Aksoy, 2019). 
Çizelge 2. MAP ambalajlamanın $6^{\circ} \mathrm{C}^{\prime}$ de 6 ay muhafaza edilen 'Katırbaşı' nar çeşidinde ağırlık kaybı, görünüş, tat, usare miktarı, mantarsal ve fizyolojik bozulmalar ve fizyolojik bozulma şiddeti üzerine etkileri

Table 2. Effects of MAP packaging on weight loss, appearance, taste, juice content, incidence of fungal decay and physiological disorder and physiological disorder severity in 'Katırbaşı' pomegranate cultivar during 6 months of storage at $6^{\circ} \mathrm{C}$

\begin{tabular}{|c|c|c|c|c|c|c|c|}
\hline Muhafaza & $\begin{array}{c}\text { Ağırlık kaybı } \\
(\%)\end{array}$ & $\begin{array}{c}\text { Görünüş (1- } \\
5)\end{array}$ & $\begin{array}{l}\text { Tat } \\
(1-9)\end{array}$ & $\begin{array}{c}\text { Usare } \\
\text { miktarı (\%) }\end{array}$ & $\begin{array}{c}\text { Mantarsal } \\
\text { bozulma (\%) }\end{array}$ & $\begin{array}{c}\text { Fizyolojik } \\
\text { bozulma } \\
(\%)\end{array}$ & $\begin{array}{c}\text { Fizyolojik } \\
\text { bozulma şiddeti } \\
(1-5)\end{array}$ \\
\hline \multicolumn{8}{|c|}{ Soğukta muhafaza ambalaj } \\
\hline Kontrol & $10.78 \mathrm{a}$ & $3.14 \mathrm{~b}$ & 7.32 & 40.14 & $4.44 \mathrm{~b}$ & 21.33 & $1.89 \mathrm{a}$ \\
\hline MAP & $4.61 \mathrm{~b}$ & $4.19 \mathrm{a}$ & 7.10 & 38.24 & $11.33 \mathrm{a}$ & 21.56 & $1.48 \mathrm{~b}$ \\
\hline D\%5 (ambalaj) & 0.59 & 0.17 & Ö.D. & Ö.D. & 4.20 & Ö.D. & 0.28 \\
\hline \multicolumn{8}{|c|}{ Soğukta muhafaza süresi (ay) } \\
\hline 0 & --- & $5.00 \mathrm{a}$ & $9.00 \mathrm{a}$ & 42.76 & --- & --- & $1.00 \mathrm{c}$ \\
\hline 1 & $2.62 \mathrm{e}$ & $5.00 \mathrm{a}$ & $8.39 \mathrm{a}$ & 37.21 & $0.00 \mathrm{c}$ & $0.00 \mathrm{c}$ & $1.00 \mathrm{c}$ \\
\hline 2 & $5.48 d$ & $4.67 \mathrm{a}$ & $7.75 a b$ & 36.47 & $0.00 \mathrm{c}$ & $0.00 \mathrm{c}$ & $1.00 \mathrm{c}$ \\
\hline 3 & $7.74 \mathrm{c}$ & $3.50 \mathrm{~b}$ & $6.67 \mathrm{bc}$ & 38.97 & $0.00 \mathrm{c}$ & $10.56 \mathrm{c}$ & $1.33 \mathrm{~b}$ \\
\hline 4 & $9.48 b$ & $2.07 \mathrm{c}$ & $5.59 \mathrm{c}$ & 40.46 & $8.34 \mathrm{~b}$ & $26.67 \mathrm{~b}$ & $2.88 \mathrm{a}$ \\
\hline 5 & $13.15 \mathrm{a}$ & $1.75 \mathrm{c}$ & $5.88 \mathrm{c}$ & 39.27 & $31.11 \mathrm{a}$ & $70.00 \mathrm{a}$ & $2.91 \mathrm{a}$ \\
\hline $\mathrm{D}_{\% 5}$ (muhafaza) & 1.12 & 0.44 & 1.63 & Ö.D. & 9.52 & 12.92 & 0.73 \\
\hline \multicolumn{8}{|l|}{ Raf ömrü ambalaj } \\
\hline Kontrol (Control) & $2.94 \mathrm{~b}$ & $2.78 \mathrm{~b}$ & 7.32 & $41.52 \mathrm{a}$ & 13.70 & $27.04 \mathrm{a}$ & 1.74 \\
\hline MAP & $3.23 \mathrm{a}$ & $3.64 \mathrm{a}$ & 7.49 & $37.16 \mathrm{~b}$ & 10.74 & $23.52 \mathrm{~b}$ & 1.69 \\
\hline $\mathrm{D}_{\% 5 \text { (ambalaj) }}$ & 0.22 & 0.17 & Ö.D. & 4.25 & Ö.D. & 3.29 & Ö.D. \\
\hline \multicolumn{8}{|c|}{ Raf ömrü süresi (ay + gün) } \\
\hline $0+7$ & $6.35 a$ & $5.00 \mathrm{a}$ & $9.00 \mathrm{a}$ & 37.81 & $0.00 \mathrm{c}$ & $0.00 \mathrm{~d}$ & $1.00 \mathrm{e}$ \\
\hline $1+7$ & $3.39 \mathrm{~b}$ & $5.00 \mathrm{a}$ & $9.00 \mathrm{a}$ & 41.32 & $0.00 \mathrm{c}$ & $0.00 \mathrm{~d}$ & $1.00 \mathrm{e}$ \\
\hline $2+7$ & $2.60 \mathrm{c}$ & $3.68 b$ & $8.25 \mathrm{~b}$ & 38.27 & $1.11 \mathrm{c}$ & $23.89 c$ & $1.48 \mathrm{~d}$ \\
\hline $3+7$ & $1.91 \mathrm{~d}$ & $3.02 \mathrm{c}$ & $7.08 \mathrm{c}$ & 41.54 & $0.00 \mathrm{c}$ & $24.45 c$ & $2.00 \mathrm{~b}$ \\
\hline $4+7$ & $2.11 \mathrm{~cd}$ & $1.37 \mathrm{~d}$ & $5.92 \mathrm{~d}$ & 41.08 & $22.22 \mathrm{~b}$ & $45.00 \mathrm{~b}$ & $1.95 \mathrm{c}$ \\
\hline $5+7$ & $2.13 \mathrm{~cd}$ & $1.20 \mathrm{e}$ & $5.17 \mathrm{e}$ & 36.01 & $50.00 \mathrm{a}$ & $58.34 \mathrm{a}$ & $2.87 \mathrm{a}$ \\
\hline D\%5 (raf ömrü) & 0.49 & 0.06 & 0.07 & Ö.D. & 6.35 & 8.53 & 0.01 \\
\hline
\end{tabular}

Ö.D.: Önemli değil

\section{Usare miktarı}

'Hicaznar' nar çeşidinde başlangıçta ortalama \%47.13 olan usare miktarı muhafaza süresi uzadıkça azalışlar göstermiş ve 6 ayın sonunda \%35.52'ye düşmüştür. Usare miktarı MAP ambalajda (ortalama \%41.09) kontrolden (\%43.44) daha düşük olmuştur. Raf ömrü sırasında başlangıçta ortalama \%54.86 olan usare miktarı raf ömrü süresi uzadıkça azalışlar göstermiş ve 6 ayın sonunda \%36.75'e düşmüştür. Ancak, raf ömrü sırasında usare miktarında ambalajlar arasındaki farklar istatistiksel olarak benzer bulunmuştur (Çizelge 1) 'Katırbaşı' nar çeşidinde usare miktarı üzerine muhafaza süresi ile ambalajların etkisi istatistiksel olarak önemsiz bulunmuştur. Raf ömrü sırasında usare miktarı üzerine raf ömrü süresinin etkisi de istatistiksel olarak benzer bulunmuştur. Raf ömrü sırasında usare miktarı MAP ambalajda (ortalama \%37.16) kontrolden (\%41.52) daha düşük olmuştur (Çizelge 2).

\section{Mantarsal bozulmalar}

'Hicaznar' nar çeşidinde ilk 4 ay mantarsal bozulma görülmemiş, 5. ayda ortalama \%10.00 ve 6 ayın sonunda \%7.78 olmuştur. Mantarsal bozulmalar MAP ambalajda (ortalama \%5.56) kontrolden (\%0.37) daha yüksek olmuştur. Raf ömrü sırasında pek fazla görülmemesine rağmen, özellikle 6 . ayda mantarsal bozulmalar çok olmuş ve ortalama \%11.11'e ulaşmıştır. Ancak, raf ömrü sırasında mantarsal bozulmalarda ambalajlar arasındaki farklar istatistiksel olarak benzer bulunmuştur (Çizelge 1). 'Katırbaşı' nar çeşidinde ilk 3 ay mantarsal bozulma görülmemiş, 4. ay sonunda ortalama $\% 8.34$ ve 5 ayın sonunda \%31.11 olmuştur. Mantarsal bozulmalar MAP ambalajda (ortalama \%11.33) kontrolden (\%4.44) daha yüksek olmuştur. Raf ömrü sırasında pek fazla 
görülmemesine rağmen, özellikle 4. ayda (ortalama $\% 22.22)$ ve 5 . ayda $(\% 50.00)$ ile çok fazla mantarsal bozulma olmuştur. Ancak, raf ömrü sırasında mantarsal bozulmalarda ambalajlar arasındaki farklar istatistiksel olarak önemsiz bulunmuştur (Çizelge 2). Nar meyvelerinin depolanması sırasında en fazla görülen gri küf ve iç çürüklüğü (Şen ve ark., 2013; Çandır ve ark., 2019) gibi mantarsal çürümeler meydana gelmiştir. Nar meyvelerinin muhafazası sırasında $\left(5-10{ }^{\circ} \mathrm{C}\right.$ 'de $>\% 90$ oransal nemde) herhangi bir fungusit uygulaması yapılmamışsa özellikle etmeni Botrytis cinerea olan gri küf kökenli çürümelerden kaynaklı ürün kaybı \%30'lara ulaşmaktadır (Tedford ve ark., 2005). Nar muhafazası konusunda yapılan çalışmaların sonucuna göre, mantarsal çürümelerin depolama periyodunun son aylarında ortaya çıkmakta olup çürüme oranı soğukta muhafaza ve raf ömrü periyodu sonrasında \%8-40 (Onur ve ark., 1992; 1995; Bayram ve ark., 2010; D’Aquino ve ark., 2010; Kirpi ve Dündar, 2011; Selçuk ve Erkan, 2013; 2014; 2015; Karaşahin ve ark., 2017; Bolel ve ark., 2019) arasında değişmektedir. Kullanılan MAP ambalaj materyaline bağıı olarak MAP ambalajların kontrole göre çürümeleri azalttığı, arttırdığı veya etkisinin olmadığı (Bayram ve ark., 2010; D'Aquino ve ark., 2010; Selçuk ve Erkan, 2013; 2014; 2015; Porat ve ark., 2016) bildirilmiştir.

\section{Fizyolojik bozulmalar ve fizyolojik bozulma şiddeti}

'Hicaznar' nar çeşidinde meyve kabuğunda görülen fizyolojik bozulmaların kararmalar şeklinde olduğu ve 'Katırbaşı' nar çeşidi meyvelerinde ise meyve kabuğunda görülen fizyolojik bozulmaların kararma ve çöküntüler şeklinde üşüme zararı olduğu saptanmıştır (Şekil 2 ve 3). 'Hicaznar' nar çeşidinde ilk 4 ay meyve kabuğunda fizyolojik bozulma görülmemiş, 5. ayda ortalama \%21.11 ve 6 ayın sonunda \%18.89 olmuştur. Muhafaza süresi sırasında meyve kabuğunda görülen fizyolojik bozulmalarda ambalajlar arasındaki farklar istatistiksel olarak önemsiz bulunmuştur. Raf ömrü sırasında ise meyve kabuğunda görülen fizyolojik bozulmalar 4. aydan (ortalama \%8.33) itibaren görülmüş, 5. ayda (\%18.89) ve 6. ayda (\%14.45) olmuştur. Raf ömrü sırasında meyve kabuğunda görülen fizyolojik bozulmalar MAP ambalajda (ortalama \%3.81) kontrolden (\%8.10) daha düşük olmuştur (Çizelge 1). 'Katırbaşı' nar çeşidinde muhafaza süresi uzadıkça meyve kabuğunda görülen fizyolojik bozulmalarda artışlar olmuş, 3. ayda ortalama \%10.56, 4 ayda \%26.67 ve 5 ayın sonunda \%70.00 olmuştur. Muhafaza süresi sırasında meyve kabuğunda görülen fizyolojik bozulmalarda ambalajlar arasındaki farklar istatistiksel olarak önemsiz bulunmuştur. Raf ömrü sırasında ise meyve kabuğunda görülen fizyolojik bozulmalar 2. aydan (ortalama \%23.89) itibaren görülmüş, 3. ayda $\% 24.45,4$. ayda $\% 45.00$ ) ve 5 . ayda \%58.34 olmuştur. Raf ömrü sırasında meyve kabuğunda görülen fizyolojik bozulmalar MAP ambalajda (ortalama \%23.52) kontrolden (\%27.04) daha düşük olmuştur (Çizelge 2).

'Hicaznar' nar çeşidinde fizyolojik bozulma şiddeti fizyolojik bozulmalara benzer şekilde 5 . ayda ortalama 1.22 ve 6 ayın sonunda 1.20 olmuş ve kabul edilebilir seviyede bulunmuştur. Muhafaza süresi sırasında görülen fizyolojik bozulma şiddetinde ambalajlar arasındaki farklar istatistiksel olarak önemsiz bulunmuştur. Raf ömrü sırasında fizyolojik bozulma şiddeti üzerine raf ömrü süresi ve ambalajların etkisi istatistiksel olarak önemsiz bulunmuştur (Çizelge 1). 'Katırbaş' nar çeşidinde fizyolojik bozulma şiddeti ilk görüldüğü 3. ayda ortalama 1.33, 4. ayda 2.88 ve 5 ayın sonunda 2.91 olmuş ve kabul edilebilir seviye sınırına ulaşmıştır. Fizyolojik bozulma şiddeti MAP ambalajda (ortalama 1.48) kontrolden (1.89) daha düşük olmuştur. Raf ömrü sırasında ise 2. ayda ortalama $1.48,3$. ayda ortalama $2.00,4$. ayda 1.95 ve 5 ayın sonunda 2.87 olmuş ve kabul edilebilir seviye sınırına ulaşmıştır. Ancak, raf ömrü sırasında fizyolojik bozulma şiddetinde ambalajlar arasındaki farklar istatistiksel olarak önemsiz bulunmuştur (Çizelge 2). $5{ }^{\circ} \mathrm{C}^{\prime}$ nin altındaki sıcaklıklarda iki aydan daha uzun bir süre muhafaza edilen nar meyvelerinde görülen gelen üşüme zararı (Elyatem ve Kader 1984) ve $7{ }^{\circ} \mathrm{C}$ 'de uzun süre depolandığında kabukta görülen yüzeysel yanıklar (Ben-Arie ve Or, 1986) narların pazarlanmasını sınırlayan en önemli fizyolojik bozulmalardır. 


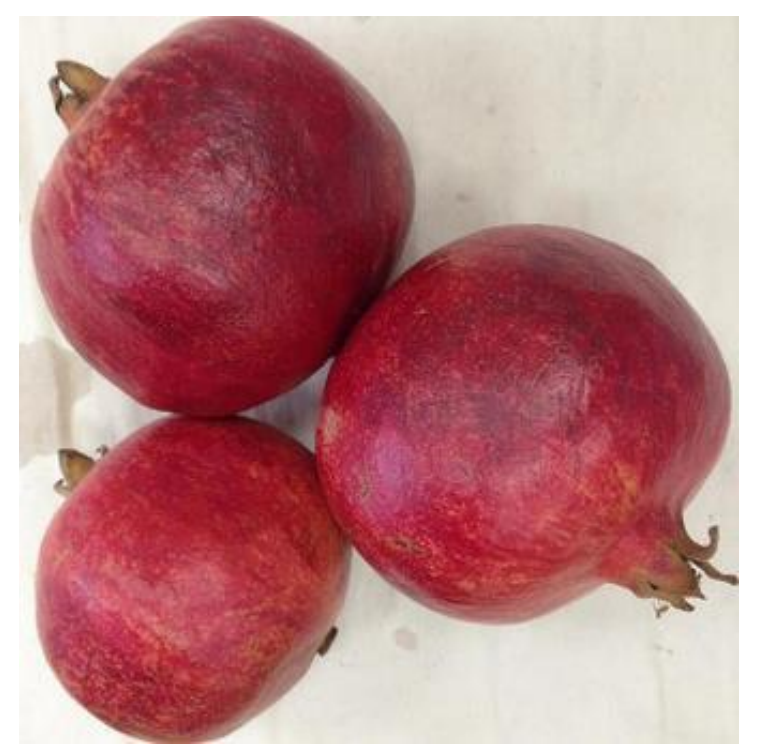

Şekil 2. Muhafazanın 5. ayında 'Hicaznar' nar çeşidi kontrol meyvelerinde meyve kabuğunda görülen fizyolojik bozulmalar (Kabukta kararmalar).

Figure 2. Physiological disorders in the husk of the control fruits of the 'Hicaznar' pomegranate variety in the 5th month of storage (blackout in the husk).

Üşüme zararının belirtileri kabuk yüzeyinde çukurların oluşması, kabukta kahverengi renk oluşumu, tane renginin solması, taneleri çevreleyen beyaz kısmın kahverengileşmesi ve mantarsal bozulmaların artması olarak bildirilmiştir (Elyatem ve Kader, 1984; Artes ve ark., 2000). Nar meyvelerinde yüzeysel kabuk yanıklığı meyve sapına yakın kabuk dokusunda ortaya çıkmakta olup taneleri ve taneleri çevreleyen dokularını etkilemeyen, meyve kabuğunun yaklaşık $\% 60$ 'ında kahverengi renk oluşumu olarak tanımlanmaktadır (Defilippi ve ark., 2006). Yüzeysel kabuk yanıklığının nar meyvelerindeki üşüme zararından farklı olarak üşüme sıcaklığın üzerinde uzun süre (4-6 ay) depolanan ve daha çok geç derilen meyvelerde görülmesi yaşlanma ile ilgili olduğunu göstermektedir (Defilippi ve ark., 2006). Bulgularımıza benzer olarak, Aksoy (2019) tarafından yürütülen bir çalışmada, 'Hicaznar' nar çeşidi meyvelerinde depolama sıcaklığı $6{ }^{\circ} \mathrm{C}$ olup, meyve kabuğunda veya tanelerde üşüme zararından kaynaklanan herhangi bir bozulma olmamıştır. Ancak, çalışmamızda 'Hicaznar' nar çeşidinde soğukta muhafaza ve raf ömrü periyodunda yüzeysel kabuk yanıklığı olarak tanımlanan fizyolojik bozulma gösteren meyve indeksi tüm uygulamalarda düşük olup, "meyve yüzeyinin \%10'unda kahverengileşme" şekline meydana gelirken, fizyolojik bozulma şiddeti 'Katırbaşı' nar çeşidinde 4. aydan itibaren kabul edilebilir sınır olan $3^{\prime}$ ün üstüne çıkmıştır. Bulgularımızla paralel olarak, $7{ }^{\circ} \mathrm{C}^{\prime}$ de 4 ay muhafaza edilen ve depolamadan sonra $20^{\circ} \mathrm{C}$ 'de 1 hafta bekletilen 'Wonderful' nar çeşidinde $\mathrm{Xtend}^{\circledR} \mathrm{MAP}$ ambalaj uygulamasında (\%6) Kontrol uygulamasından (\%29) daha düşük oranda yüzeysel kabuk yanıklığı meydana gelmiştir (Porat ve ark., 2016). D'Aquino ve ark. (2010) tarafından 'Primosole' nar çeşidinde yapılan çalışmada $8{ }^{\circ} \mathrm{C}$ 'de 12 hafta depolama ve depolamadan sonra raf ömrü ( $20^{\circ} \mathrm{C}^{\prime}$ de 1 hafta) periyodunda yüzeysel kabuk yanıklığı gösteren meyve oranının kontrol uygulamasında \%78 iken, MAP ambalajda depolanan meyvelerde soğukta muhafaza sırasında yüzeysel kabuk yanıklığı görülmediği ve raf ömrü periyodunda ise oldukça düşük oranda (\%2) olduğu bildirilmiştir. 


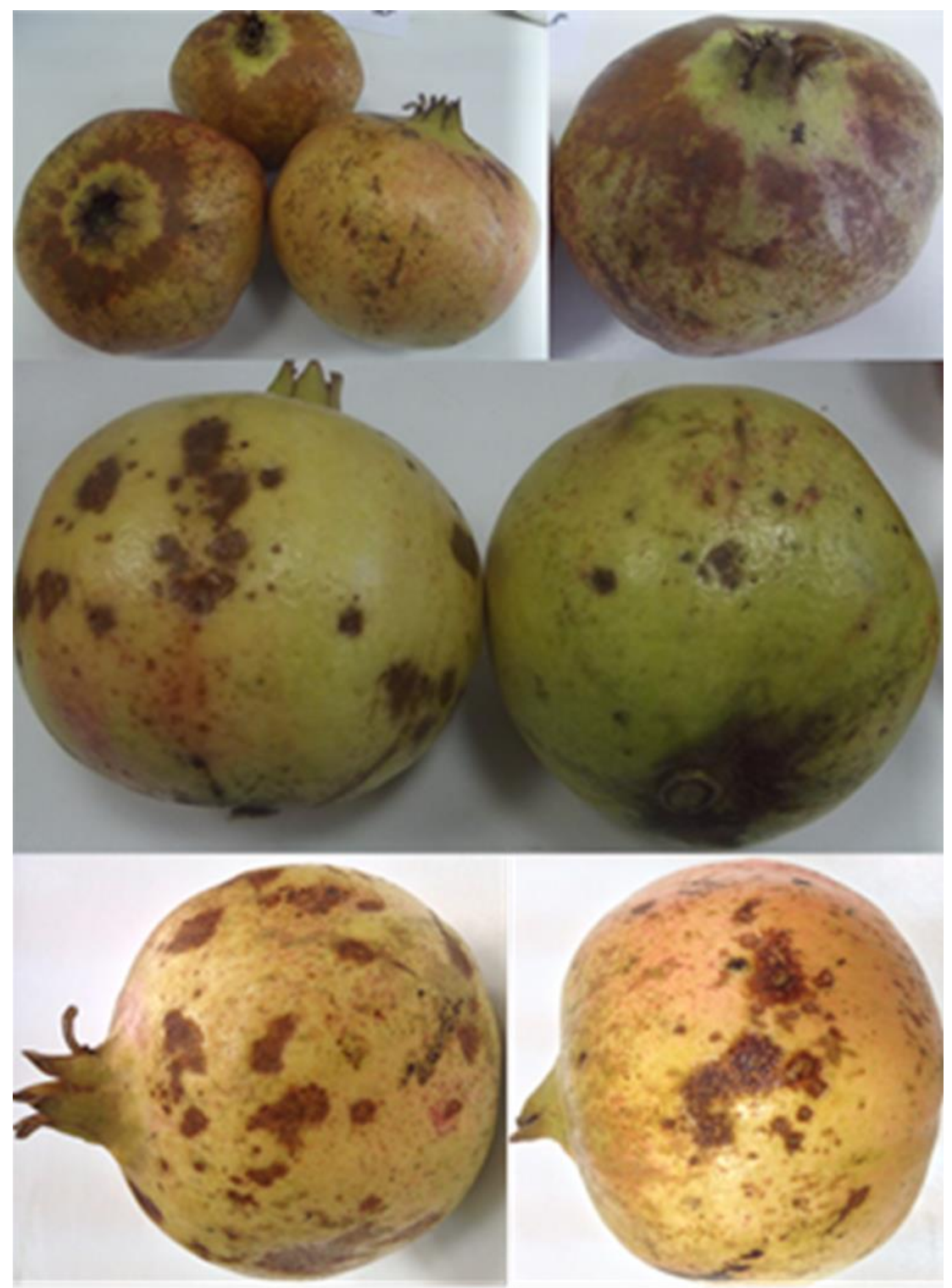

Şekil 3. Muhafazanın 3. ayında üstte 'Katırbaşı' nar çeşidi kontrol meyvelerinde, ortada ve altta MAP meyvelerinde meyve kabuğunda görülen fizyolojik bozulmalar (üşüme zararı).

Figure 3. Physiological disorders in the husk of the control fruits 'Katırbaşı' pomegranate variety on top, and MAP fruits in the middle and bottom in the 3nd month of storage (chilling injury).

\section{Meyve kabuk ve tane rengi $L^{*}$ ve $h^{\circ}$ değerleri}

'Hicaznar' nar çeşidinde muhafaza süresince başlangıçta ortalama 43.97 olan meyve kabuk rengi $L^{*}$ değerinde muhafaza süresi uzadıkça azalmalar olmuş ve 6 ayın sonunda 40.01'e düşmüştür. Meyve kabuk rengi L* değeri MAP ambalajda (ortalama 42.56) kontrolden (43.61) daha düşük olmuştur. Raf ömrü sırasında başlangıçta ortalama 40.26 olan meyve kabuk rengi L* değeri artışlar göstermiş ve 6 ayın sonunda 45.08'e ulaşmıştır. Ancak, raf ömrü sırasında meyve kabuk rengi $L^{*}$ değerinde ambalajlar arasındaki farklar istatistiksel olarak önemsiz bulunmuştur (Çizelge 3). 'Katırbaşı' nar çeşidinde meyve kabuk rengi $L^{*}$ değeri üzerine muhafaza süresinin etkisi istatistiksel olarak önemsiz bulunmuştur.
Meyve kabuk rengi L* değeri MAP ambalajda (ortalama 64.94) kontrolden (59.82) daha yüksek olmuştur. Raf ömrü sırasında başlangıçta ortalama 63.37 olan meyve kabuk rengi $L^{*}$ değeri 5 ayın sonunda azalarak 57.11'e düşmüştür. Raf ömrü sırasında meyve kabuk rengi $L^{*}$ değeri MAP ambalajda (ortalama 64.09) kontrolden (57.92) daha düşük olmuştur (Çizelge 4). Bulgularımızla uyumlu olarak, önceki çalışmalarda açıkta veya MAP ambalajda depolanan nar meyvelerinde soğukta muhafaza ve raf ömrü periyodu süresince kabuk rengi L* değerinin (D'Aquino ve ark., 2010; Selçuk ve Erkan, 2013; 2014; 2016; Aksoy, 2019) azaldığı belirlenmiştir. Bulgularımızdan farklı olarak, Şen ve Eroğul (2012), Öz ve ark. (2015) ve Bolel ve ark. (2019) tarafindan nar 
meyvelerinin soğukta muhafaza periyodu süresince kabuk rengi $L^{*}$ değerinin arttığı bildirilmiştir.

'Hicaznar' nar çeşidinde meyve kabuk rengi $h^{\circ}$ değeri üzerine muhafaza süresi ve ambalajların etkisi istatistiksel olarak önemsiz bulunmuştur. Raf ömrü sırasında başlangıçta $22.43^{\circ}$ olan meyve kabuk rengi $\mathrm{h}^{\circ}$ değeri 5 ayın sonunda artarak $30.80^{\circ}$ olmuştur. Ancak, raf ömrü sırasında meyve kabuk rengi $h^{\circ}$ değerinde ambalajlar arasındaki farklar istatistiksel olarak önemsiz bulunmuştur (Çizelge 3). 'Katırbaşı' nar başlangıçta ortalama $70.34^{\circ}$ olan meyve kabuk rengi $h^{\circ}$ değerinde muhafaza süresi uzadıkça artış ve azalışlar olmuş ve azalarak 5 ayın sonunda $64.21^{\circ}$ ye düşmüştür. Meyve kabuk rengi $h^{\circ}$ değeri MAP ambalajda (ortalama $67.43^{\circ}$ ) kontrolden $\left(60.19^{\circ}\right)$ daha yüksek olmuştur. Raf ömrü sırasında meyve kabuk rengi $h^{\circ}$ değeri üzerine raf ömrü süresinin etkisi istatistiksel olarak önemsiz bulunmuştur. Raf ömrü sırasında meyve kabuk rengi $h^{\circ}$ değeri MAP ambalajda (ortalama $67.54^{\circ}$ ) kontrolden $\left(60.82^{\circ}\right)$ daha yüksek olmuştur (Çizelge 4). Bulgularımızla uyumlu olarak, önceki çalışmalarda açıkta veya MAP ambalajda depolanan nar meyvelerinde soğukta muhafaza ve raf ömrü periyodu süresince kabuk rengi $h^{\circ}$ değerinin arttığı (Palou ve ark., 2007; Selçuk ve Erkan, 2013; 2014; 2015; Aksoy, 2019) bildirilmiştir. 'Hicaznar' nar çeşidinde tane rengi $L^{*}$ değeri üzerine muhafaza ve raf ömrü süresi ile ambalajların etkisi istatistiksel olarak önemsiz bulunmuştur (Çizelge 3). 'Katırbaşı' nar çeşidinde tane rengi $L^{*}$ değeri üzerine muhafaza ve raf ömrü süresi ile ambalajların etkisi istatistiksel olarak önemsiz bulunmuştur (Çizelge 4) Bulgularımızdan farklı olarak, Arendse ve ark. (2015) 'Wonderful' çeşidinde yaptıkları çalışmada, $5^{\circ} \mathrm{C}^{\prime}$ de 2 ay depolamadan sonra tane rengi $L^{*}$ değerinde az miktarda artış ve daha sonraki periyotta azalma meydana gelmiştir. Benzer olarak, Varasteh ve ark. (2012) tarafından yapılan çalışmada $2-5^{\circ} \mathrm{C}^{\prime}$ de 135 gün depolanan 'Rabbab-e105 Neyriz' çeşidi nar meyvelerinde 45 . günden sonra meyve suyu rengi $L^{*}$ değeri azalmıştır.

'Hicaznar' nar çeşidinde tane rengi $h^{\circ}$ değeri üzerine muhafaza ve raf ömrü süresi ile ambalajların etkisi istatistiksel olarak önemsiz bulunmuştur (Çizelge 3 ). 'Katırbaşı' nar çeşidinde tane rengi $h^{\circ}$ değeri üzerine muhafaza süresi ile ambalajların etkisi istatistiksel olarak önemsiz bulunmuştur. Raf ömrü süresince başlangıçta ortalama $56.55^{\circ}$ olan tane rengi $h^{\circ}$ değerinde raf ömrü süresi uzadıkça azalışlar olmuş ve 5 ayın sonunda $36.77^{\circ}$ ye düşmüştür. Ancak, raf ömrü sırasında tane rengi $h^{\circ}$ değerinde ambalajlar arasındaki farklar istatistiksel olarak önemsiz bulunmuştur (Çizelge 4). Tane renginde soğukta muhafaza ve raf ömrü periyodunda önemli bir değişim meydana gelmediğinden, tane renginde bozulmaların olmadığını değerlendirilmiştir. Bulgularımızla uyumlu olarak, muhafaza sırasında uygulamaların tane rengi $h^{\circ}$ değeri üzerine etkisi Aksoy (2019) tarafından da önemsiz bulunmuştur. Bulgularımızdan farklı olarak, Arendse ve ark. (2015) 'Wonderful' çeşidinde yaptıkları çalışmada, 5 ${ }^{\circ} \mathrm{C}^{\prime}$ de 2 ay depolamadan sonra tane rengi h ${ }^{\circ}$ değeri ise 2 . ayda azalmış ve depolamanın sonuna doğru bir miktar artmıştır. Benzer olarak, Varasteh ve ark. (2012) tarafından yapılan çalışmada $2-5{ }^{\circ} C^{\prime}$ de 135 gün depolanan 'Rabbab-e105 Neyriz' çeşidi nar meyvelerinde 45. günden sonra meyve suyu rengi ${ }^{\circ}{ }^{\circ}$ değeri azalmıştır.

\section{SÇKM miktarı}

'Hicaznar' nar çeşidinde başlangıçta ortalama \%17.47 olan SÇKM miktarı muhafaza süresi uzadıkça artış ve azalışlar göstermiş ve 6 ayın sonunda biraz azalarak \%16.77'ye düşmüştür. Raf ömrü sırasında da başlangıçta ortalama \%17.80 olan SÇKM miktarı raf ömrü süresi uzadıkça azalış ve artışlar göstermiş ve 6 ayın sonunda biraz azalarak \%16.95'e düşmüştür. Ancak, muhafaza süresi ve raf ömrü sırasında SÇKM miktarında ambalajlar arasındaki farklar istatistiksel olarak önemsiz bulunmuştur (Çizelge 3). 'Katırbaşı' nar çeşidinde başlangıçta ortalama \%16.00 olan SÇKM miktarı muhafaza süresi uzadıkça artış ve azalışlar göstermiş ve 5 ayın sonunda biraz azalarak \%15.15'e düşsüştür. Raf ömrü sırasında da başlangıçta ortalama \%15.33 olan SÇKM miktarı raf ömrü süresi uzadıkça azalış ve artışlar göstermiş ve 5 ayın sonunda biraz artarak \%15.95 olmuştur. Ancak, muhafaza süresi ve raf ömrü sırasında SÇKM miktarında ambalajlar arasındaki farklar istatistiksel olarak önemsiz bulunmuştur (Çizelge 4). Nar derimden sonra olgunlaşmaya devam etmeyen bir meyve olup (Elyatem ve Kader 1984) depolama sırasında şekerlerin solunumda kullanılması sonucu SÇKM miktarında azalmalar meydana gelebilmektedir (Şen ve Eroğul, 2012; Fawole ve Opara, 2013; Selçuk ve Erkan, 2016). Daha önce yapılan çalışmalarda, nar meyvesinde soğukta depolama ve raf ömrü periyodunda SÇKM miktarında az veya önemli miktarda azalmalar meydana geldiği (Kader ve ark., 1984; Onur ve ark., 1992; 1995; Artes ve ark., 2000; D'Aquino ve ark., 2010; Kirpi ve Dündar, 2011; Laribi ve ark., 2012; Şen ve Eroğul, 2012; Selçuk ve Erkan, 2013; 2015; 2016; Karaşahin ve ark., 2017) bildirilmiştir. Bazı çalışmalarda soğukta muhafaza ve raf ömrü periyodunda ise kontrol ve MAP ambalajları arasında SÇKM miktarı bakımından farklııı bazı çalışmalarda önemsiz bulunurken (Nanda ve ark., 2001; Laribi ve ark., 2012; Selçuk ve Erkan, 2013; 2016; Aksoy, 2019), diğer çalışmalarda SÇKM miktarı kontrol meyvelerinde MAP ambalajda depolanan meyvelere 
göre daha düşük (Selçuk ve Erkan, 2014) veya daha 2010; Selçuk ve Erkan, 2015).

yüksek olmuştur (Onur ve ark., 1995; Bayram ve ark.,

Çizelge 3. MAP ambalajlamanın $6^{\circ} \mathrm{C}^{\text {' de }} 6$ ay muhafaza edilen 'Hicaznar' nar çeşidinde meyve kabuk ve tane rengi $\mathrm{L}^{*}$ ve $\mathrm{h}^{\circ}$ değerleri, suda çözünebilir toplam kuru madde (SÇKM) ve titre edilebilir asit (TEA) miktarları ile meyve suyu $\mathrm{pH}$ değeri üzerine etkileri

Table 3. Effects of MAP packaging on fruit skin and aril color $L^{*}$ and $h^{\circ}$ value, total soluble solid (TSS) and titratable acidity (TA) contents and fruit juice $\mathrm{pH}$ value in 'Hicaznar' pomegranate cultivar during 6 months of storage at $6{ }^{\circ} \mathrm{C}$

\begin{tabular}{|c|c|c|c|c|c|c|c|}
\hline \multirow{2}{*}{ Muhafaza } & \multicolumn{2}{|c|}{ Meyve kabuk rengi } & \multicolumn{2}{|c|}{ Tane rengi } & \multirow{2}{*}{$\begin{array}{c}\text { SÇKM } \\
\text { miktarı (\%) }\end{array}$} & \multirow{2}{*}{$\begin{array}{c}\text { TEA miktarı } \\
(\%)\end{array}$} & \multirow{2}{*}{$\begin{array}{l}\text { Meyve suyu } \\
\text { pH değeri }\end{array}$} \\
\hline & $L^{*}$ değeri & $\mathrm{h}^{\circ}$ değeri & $L^{*}$ değeri & $\mathrm{h}^{\circ}$ değeri & & & \\
\hline \multicolumn{8}{|c|}{ Soğukta muhafaza ambalaj } \\
\hline Kontrol & $43.61 \mathrm{a}$ & 26.05 & 30.63 & 29.89 & 17.24 & 1.28 & 3.38 \\
\hline MAP & $42.56 \mathrm{~b}$ & 25.98 & 31.47 & 29.97 & 17.14 & 1.19 & 3.40 \\
\hline $\mathrm{D}_{\% 5 \text { (ambalaj) }}$ & 0.91 & Ö.D. & Ö.D. & Ö.D. & Ö.D. & Ö.D. & Ö.D. \\
\hline \multicolumn{8}{|c|}{ Soğukta muhafaza süresi (ay) } \\
\hline 0 & $43.97 \mathrm{ab}$ & 25.18 & 32.43 & 30.98 & $17.47 \mathrm{ab}$ & 1.32 & $3.32 \mathrm{~b}$ \\
\hline 1 & $44.25 \mathrm{a}$ & 28.02 & 33.56 & 33.05 & $18.03 \mathrm{a}$ & 1.33 & $3.35 \mathrm{ab}$ \\
\hline 2 & $43.05 \mathrm{ab}$ & 25.21 & 31.09 & 28.80 & $18.12 \mathrm{a}$ & 1.40 & $3.30 \mathrm{~b}$ \\
\hline 3 & $44.89 \mathrm{a}$ & 24.43 & 29.48 & 29.50 & $17.08 \mathrm{~b}$ & 1.15 & $3.45 \mathrm{ab}$ \\
\hline 4 & $43.39 \mathrm{ab}$ & 26.69 & 29.72 & 26.77 & $17.25 \mathrm{ab}$ & 1.13 & $3.54 \mathrm{a}$ \\
\hline 5 & $41.60 \mathrm{bc}$ & 26.36 & 31.92 & 30.88 & $15.60 \mathrm{c}$ & 1.24 & $3.33 \mathrm{ab}$ \\
\hline 6 & $40.01 \mathrm{c}$ & 26.26 & 29.15 & 29.53 & $16.77 \mathrm{~b}$ & 1.05 & $3.44 \mathrm{ab}$ \\
\hline D\%5 (muhafaza) & 0.91 & Ö.D. & Ö.D. & Ö.D. & 0.92 & Ö.D. & 0.22 \\
\hline \multicolumn{8}{|c|}{ Raf ömrü ambalaj } \\
\hline Kontrol & 42.83 & 25.80 & 29.93 & 28.03 & 17.11 & 1.18 & 3.38 \\
\hline MAP & 42.25 & 24.90 & 29.14 & 29.37 & 17.13 & 1.23 & 3.35 \\
\hline$D_{\% 5 \text { (ambalaj) }}$ & Ö.D. & Ö.D. & Ö.D. & Ö.D. & Ö.D. & Ö.D. & Ö.D. \\
\hline \multicolumn{8}{|c|}{ Raf ömrü süresi (ay + gün) } \\
\hline $0+7$ & $40.26 \mathrm{ab}$ & $22.43 \mathrm{~b}$ & 34.14 & 27.55 & $17.80 \mathrm{a}$ & $1.61 \mathrm{a}$ & $3.07 \mathrm{c}$ \\
\hline $1+7$ & $41.78 \mathrm{ab}$ & $25.34 a b$ & 32.42 & 28.72 & $17.30 \mathrm{a}$ & $1.21 \mathrm{ab}$ & $3.30 \mathrm{bc}$ \\
\hline $2+7$ & $43.12 \mathrm{ab}$ & $24.48 \mathrm{~b}$ & 31.54 & 28.72 & $17.37 \mathrm{a}$ & $1.23 a b$ & $3.29 \mathrm{bc}$ \\
\hline $3+7$ & $38.55 b$ & $23.95 b$ & 30.67 & 28.72 & $17.13 \mathrm{ab}$ & $1.22 \mathrm{ab}$ & $3.33 \mathrm{ac}$ \\
\hline $4+7$ & $44.32 \mathrm{a}$ & $23.38 \mathrm{~b}$ & 25.51 & 30.27 & $16.03 \mathrm{~b}$ & $1.22 \mathrm{ab}$ & $3.40 \mathrm{ab}$ \\
\hline $5+7$ & $44.70 \mathrm{a}$ & $27.09 a b$ & 26.00 & 29.07 & $17.27 \mathrm{a}$ & $0.97 b$ & $3.57 a$ \\
\hline $6+7$ & $45.08 \mathrm{a}$ & $30.80 \mathrm{a}$ & 26.50 & 27.86 & $16.95 a b$ & $1.00 \mathrm{~b}$ & $3.60 \mathrm{a}$ \\
\hline$D_{\% 5}$ (raf ömrü) & 4.89 & 5.83 & Ö.D. & Ö.D. & 1.13 & 0.59 & 0.23 \\
\hline
\end{tabular}

Ö.D.: Önemli değil.

\section{TEA miktarı}

'Hicaznar' nar çeşidinde muhafaza sırasında TEA miktarı üzerine muhafaza süresi ile ambalajların etkisi istatistiksel olarak önemsiz bulunmuştur. Raf ömrü sırasında da başlangıçta ortalama \%1,61 olan TEA miktarı raf ömrü süresi uzadıkça azalışlar göstermiş ve 6 ayın sonunda azalarak \%1,00'e düşmüştür. Ancak, raf ömrü sırasında TEA miktarında ambalajlar arasındaki farklar istatistiksel olarak önemsiz bulunmuştur (Çizelge 3).
'Katırbaşı' nar çeşidinde muhafaza sırasında TEA miktarı üzerine muhafaza süresi ile uygulamaların etkisi istatistiksel olarak önemsiz bulunmuştur. Raf ömrü sırasında da başlangıçta ortalama \%1,44 olan TEA miktarı raf ömrü süresi uzadıkça azalışlar göstermiş ve 5 ayın sonunda azalarak \%0,94'e düşmüştür. Ancak, raf ömrü sırasında TEA miktarında ambalajlar arasındaki farklar istatistiksel olarak önemsiz bulunmuştur (Çizelge 4). 
Çizelge 4. MAP ambalajlamanın $6{ }^{\circ} \mathrm{C}^{\text {'de }} 6$ ay muhafaza edilen 'Katırbaşı' nar çeşidinde meyve kabuk ve tane rengi $\mathrm{L}^{*}$ ve $h^{\circ}$ değerleri, suda çözünebilir toplam kuru madde (SÇKM) ve titre edilebilir asit (TEA) miktarları ile meyve suyu $\mathrm{pH}$ değeri üzerine etkileri

Table 4. Effects of MAP packaging on fruit skin and aril color $L^{*}$ and $h^{\circ}$ value, total soluble solid (TSS) and titratable acidity (TA) contents and fruit juice $\mathrm{pH}$ value in 'Katırbaşı' pomegranate cultivar during 6 months of storage at $6{ }^{\circ} \mathrm{C}$

\begin{tabular}{|c|c|c|c|c|c|c|c|}
\hline \multirow{2}{*}{ Muhafaza } & \multicolumn{2}{|c|}{ Meyve kabuk rengi } & \multicolumn{2}{|c|}{ Tane rengi } & \multirow{2}{*}{$\begin{array}{c}\text { SÇKM } \\
\text { miktarı (\%) }\end{array}$} & \multirow{2}{*}{$\begin{array}{c}\text { TEA miktarı } \\
(\%)\end{array}$} & \multirow{2}{*}{$\begin{array}{c}\text { Meyve suyu } \\
\text { pH değeri }\end{array}$} \\
\hline & $L^{*}$ değeri & $h^{\circ}$ değeri & $L^{*}$ değeri & $h^{\circ}$ değeri & & & \\
\hline \multicolumn{8}{|c|}{ Soğukta muhafaza ambalaj } \\
\hline Kontrol & $59.82 \mathrm{~b}$ & $60.19 b$ & 36.64 & 39.42 & 15.71 & 1.08 & 3.26 \\
\hline MAP & $64.94 \mathrm{a}$ & $67.43 \mathrm{a}$ & 35.48 & 39.50 & 15.67 & 1.06 & 3.34 \\
\hline $\mathrm{D}_{\% 5}$ (ambalaj) & 2.40 & 4.31 & Ö.D. & Ö.D. & Ö.D. & Ö.D. & Ö.D. \\
\hline \multicolumn{8}{|c|}{ Soğukta muhafaza süresi (ay) } \\
\hline 0 & 65.65 & $70.34 \mathrm{a}$ & 36.52 & 38.70 & $16.00 \mathrm{ab}$ & 1.22 & 3.22 \\
\hline 1 & 63.88 & $65.54 a b$ & 36.27 & 35.99 & $16.23 \mathrm{a}$ & 1.17 & 3.25 \\
\hline 2 & 60.74 & $57.83 b$ & 38.90 & 38.28 & $16.00 \mathrm{ab}$ & 1.00 & 3.28 \\
\hline 3 & 62.48 & $60.73 a b$ & 38.30 & 42.31 & $15.65 a b$ & 1.09 & 3.31 \\
\hline 4 & 60.76 & $64.21 \mathrm{ab}$ & 33.54 & 38.00 & $15.12 \mathrm{~b}$ & 1.09 & 3.31 \\
\hline 5 & 60.76 & $64.21 \mathrm{ab}$ & 32.83 & 43.48 & $15.15 b$ & 0.85 & 3.43 \\
\hline $\mathrm{D}_{\% 5}$ (muhafaza) & Ö.D. & 11.17 & Ö.D. & Ö.D. & 0.90 & Ö.D. & Ö.D. \\
\hline \multicolumn{8}{|c|}{ Raf ömrü ambalaj } \\
\hline Kontrol & $57.92 \mathrm{~b}$ & $60.82 \mathrm{~b}$ & 37.29 & 42.09 & 15.41 & 1.10 & 3.65 \\
\hline MAP & $64.09 \mathrm{a}$ & $67.54 \mathrm{a}$ & 35.46 & 40.06 & 15.56 & 1.06 & 3.71 \\
\hline $\mathrm{D}_{\% 5 \text { (ambalaj) }}$ & 1.91 & 3.57 & Ö.D. & Ö.D. & Ö.D. & Ö.D. & Ö.D. \\
\hline \multicolumn{8}{|c|}{ Raf ömrü süresi (ay + gün) } \\
\hline $0+7$ & $63.37 \mathrm{a}$ & 67.67 & $54.75 \mathrm{a}$ & $56.55 \mathrm{a}$ & $15.33 \mathrm{~d}$ & $1.44 \mathrm{a}$ & $5.40 \mathrm{a}$ \\
\hline $1+7$ & $63.21 \mathrm{a}$ & 64.63 & $31.44 \mathrm{~b}$ & $37.95 \mathrm{~b}$ & $15.63 \mathrm{bc}$ & $1.07 \mathrm{~b}$ & $3.16 \mathrm{~d}$ \\
\hline $2+7$ & $61.88 \mathrm{ab}$ & 65.62 & $38.90 \mathrm{~b}$ & $38.28 b$ & $15.75 a b$ & $1.07 \mathrm{~b}$ & $3.28 \mathrm{~cd}$ \\
\hline $3+7$ & $61.15 \mathrm{ab}$ & 65.78 & $31.04 \mathrm{~b}$ & $38.98 \mathrm{~b}$ & $15.50 \mathrm{~cd}$ & $1.14 \mathrm{~b}$ & $3.22 \mathrm{c}$ \\
\hline $4+7$ & $59.32 \mathrm{ab}$ & 61.97 & $30.79 b$ & 37.92 b & $14.73 \mathrm{e}$ & $0.82 \mathrm{~d}$ & $3.58 b$ \\
\hline $5+7$ & $57.11 \mathrm{~b}$ & 59.42 & $31.35 \mathrm{~b}$ & $36.77 \mathrm{~b}$ & $15.95 \mathrm{a}$ & $0.94 \mathrm{c}$ & $3.44 \mathrm{bc}$ \\
\hline $\mathrm{D}_{\% 5 \text { (raf ömrü) }}$ & 4.96 & Ö.D. & 10.65 & 11.90 & 0.20 & 0.03 & 0.23 \\
\hline
\end{tabular}

Ö.D.: Önemli değil.

Bulgularımızla uyumlu olarak, 'Beynarı', 'Canernar-1', 'Göknarı', 'Ganesh', 'Hicaznar', 'Mollar de Elche' ve 'Wonderful' çeşitlerinde yapılan çalışmaların sonucuna göre nar meyvelerinin TEA miktarı soğukta muhafaza ve/veya takiben raf ömrü periyodunda azalmakta olduğu saptanmıştır (Kader ve ark., 1984; Artes ve ark., 2000; Nanda ve ark., 2001; D’Aquino ve ark., 2010; Kirpi ve Dündar, 2011; Laribi ve ark., 2012; Şen ve Eroğlu, 2012; Arendse ve ark., 2014; Oğuz ve ark., 2014; Selçuk ve Erkan , 2013; 2014; 2015; 2016; Karaşahin ve ark., 2017; Aksoy, 2019). Bazı çalışmalarda asit kaybı ve pH artışı soğukta muhafaza ve raf ömrü periyodunda MAP ambalajda kontrol uygulamasına göre daha fazla olurken (Artes ve Tomas-Barberan, 2000; D'Aquino ve ark., 2010), diğer çalışmalarda MAP ambalajların asit kaybını azalttığı (Nanda ve ark., 2001; Selçuk ve Erkan, 2014) veya etkilemediği (Laribi ve ark., 2012; Selçuk ve Erkan,
2013; 2015; 2016) bildirilmiştir.

\section{Meyve suyu $\mathrm{pH}$ değeri}

'Hicaznar' nar çeşidinde başlangıçta ortalama 3.32 olan meyve suyu $\mathrm{pH}$ değeri muhafaza süresi uzadıkça artış ve azalışlar göstermiş ve 6 ayın sonunda artarak 3.44'e ulaşmıştır. Muhafaza sırasında meyve suyu pH değerinde ambalajlar arasındaki farklar istatistiksel olarak önemsiz bulunmuştur. Raf ömrü sırasında da başlangıçta ortalama 3.07 olan meyve suyu pH değeri raf ömrü süresi uzadıkça genelde artışlar göstermiş ve 6 ayın sonunda artarak 3.60 olmuştur. Ancak, raf ömrü sırasında meyve suyu $\mathrm{pH}$ değerinde ambalajlar arasındaki farklar istatistiksel olarak benzer bulunmuştur (Çizelge 3). 'Katırbaşı' nar çeşidinde muhafaza sırasında meyve suyu $\mathrm{pH}$ değeri üzerine muhafaza süresi ile ambalajların etkisi istatistiksel olarak önemsiz bulunmuştur. Raf ömrü 
sırasında da başlangıçta ortalama 5.40 olan meyve suyu pH değeri raf ömrü süresi uzadıkça azalış ve artışlar göstermiş ve 5 ayın sonunda azalarak 3.60 olmuştur. Ancak, raf ömrü sırasında meyve suyu $\mathrm{pH}$ değerinde ambalajlar arasındaki farklar istatistiksel olarak önemsiz bulunmuştur (Çizelge 4). 'Hicaznar' nar çeşidindeki bulgularımıza benzer olarak, Aksoy (2019) tarafından yürütülen bir çalışmada, $6{ }^{\circ} \mathrm{C}^{\prime}$ de MAP ambalajında depolanan 'Hicaznar' nar çeşidi meyvelerinde meyve suyu $\mathrm{pH}$ değeri üzerine ambalajların etkisi istatistiksel olarak önemsiz bulunmuştur. Bulgularımıza benzer olarak, muhafaza süresi uzadıkça meyve suyu $\mathrm{pH}$ değerindeki artışlar olduğu birçok araştırıcı tarafından saptanmıştır (Kader ve ark., 1984; D’Aquino ve ark., 2010; Aksoy, 2019). 'Katırbaşı' nar çeşidindeki bulgularımıza benzer olarak, yapılan diğer çalışmalarda bu değişimin soğukta muhafaza sırasında önemsiz olduğu (Gil ve ark., 1996; Artes ve ark., 1998), bulgularımızdan farklı olarak, soğukta muhafazadan sonra raf ömrü periyodunda $\mathrm{pH}^{\prime}$ da artış olduğu (Artes ve ark., 1998) bildirilmiştir.

Sonuç olarak, 'Hicaznar' ve 'Katırbaşı' nar çeşitleri meyvelerinin soğukta muhafaza periyodu sonunda MAP ambalajlarında $\mathrm{O}_{2}$ konsantrasyonları sırasıyla $\% 15.83$ ve \%15.38 ile $\mathrm{CO}_{2}$ konsantrasyonları sırasıyla \%7.63 ve \%7.36 değerlerine ulaşarak denge atmosferi sağlanmıştır. MAP ambalajı her iki çeşitte de kontrole göre ağırlık kaybını azaltmada etkili olmuştur. 'Hicaznar' nar çeşidi meyvelerinin soğukta muhafaza süresince görünüş puanları MAP ambalajlarda tüketici tarafından kabul edilebilirliklerini 6 ay sonunda bile kaybetmezken, kontrol meyvelerinde görünüş puanları 5. ayda kabul edilebilir puanların (>3) altına düşmüştür. 'Katırbaşı' nar çeşidi meyvelerinin soğukta muhafaza süresince görünüş puanları MAP ambalajlarda 5. ayda ve kontrol meyvelerinde 3. ayda kabul edilebilir puanların altına düşmüştür. Mantarsal bozulmalar 'Hicaznar' nar çeşidi meyvelerinde 5. aydan itibaren görülürken, 'Katırbaşı' nar çeşidi meyvelerinde 4 . aydan itibaren görülmüştür. Fizyolojik bozulmalar 'Hicaznar' nar çeşidi meyvelerinde 5. aydan itibaren görülürken, 'Katırbaşı' nar çeşidi meyvelerinde 3 . aydan itibaren görülmüş olmakla birlikte 'Hicaznar' nar çeşidi meyvelerinde fizyolojik bozulma şiddeti düşük olup, “meyve yüzeyinin \%10'unda kahverengileşme" şeklinde meydana gelirken, 'Katırbaşı' nar çeşidinde 4. aydan itibaren kabul edilebilir sınır olan 3 ün üstüne çıkmıştır (Şekil 4). 'Hicaznar' ve 'Katırbaşı' nar çeşitlerinde muhafaza ve raf ömrü sırasında tat puanları 6 ay sonunda bile kabul edilebilir değerlerin $(>5,00)$ altına düşmemiştir.

Sonuç olarak, 'Hicaznar' nar çeşidi kontrol meyveleri $6{ }^{\circ} \mathrm{C}$ sıcaklık ve $\% 90 \pm 5$ oransal nemde 3 ay ve $20^{\circ} \mathrm{C}^{\prime}$ de 7 gün,
'Katırbaşı' nar çeşidi kontrol meyveleri $6{ }^{\circ} \mathrm{C}$ sıcaklık ve $\% 90 \pm 5$ oransal nemde 2 ay ve $20^{\circ} \mathrm{C}^{\prime}$ de 7 gün, MAP ambalaj uygulamasına ait 'Hicaznar' nar çeşidi meyveleri $6{ }^{\circ} \mathrm{C}$ sıcaklık ve $\% 90 \pm 5$ oransal nemde 4 ay ve $20^{\circ} \mathrm{C}$ 'de 7 gün ve MAP ambalaj uygulamasına ait 'Katırbaşı' nar çeşidi meyveleri $6{ }^{\circ} \mathrm{C}$ sıcaklık ve $\% 90 \pm 5$ oransal nemde 3 ay ve $20{ }^{\circ} \mathrm{C}^{\prime}$ de 7 gün süre ile kalitesinden bir şey kaybetmeden tüketiciler tarafından kabul edilebilir ve pazarlanabilir kalitede kalmışlardır. MAP ambalajda mantarsal bozulmaların azaltılmasıyla 'Hicaznar' nar çeşidi meyveleri 6 ay ve 'Katırbaşı'nar çeşidi meyveleri 5 ay depolanabilecektir. 


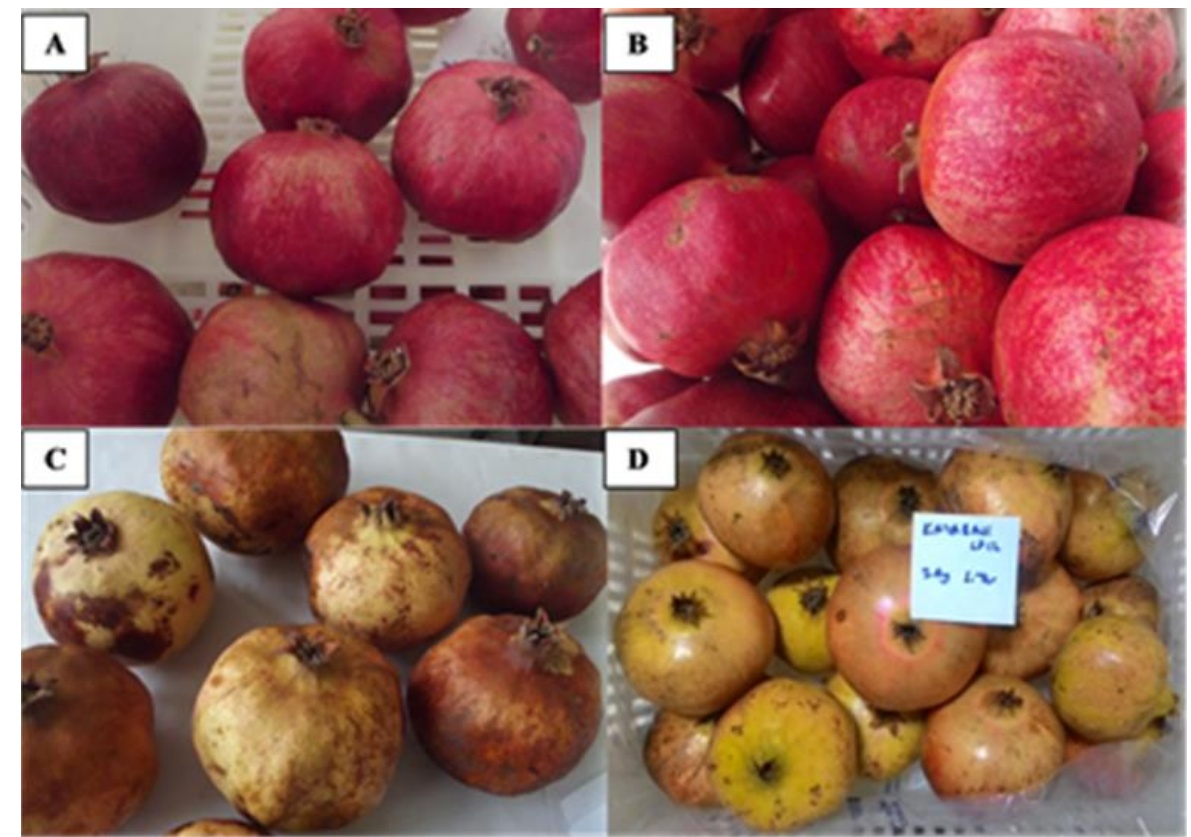

Şekil 4. $6^{\circ} \mathrm{C}^{\prime}$ de 4 ay soğukta muhafaza edilmiş 'Hicaznar' (A: Kontrol ve B: MAP) ve 3 ay soğukta muhafaza edilmiş

'Katırbaşı' (C: Kontrol ve D: MAP) nar çeşitlerine meyvelerinin görünümler.

Figure 4. The appearance of the fruits of 'Hicaznar' stored at $6{ }^{\circ} \mathrm{C}$ for 4 months (A: Control and B: MAP) and 'Katırbaşı' pomegranate cultivars stored for 3 months (C: Control and D: MAP) in cold storage.

\section{ÖZET}

Amaç: Bu çalışmanın amacı Hatay ilinde yetiştirilen 'Hicaznar' ve 'Katırbaşı' nar çeşitlerinde soğukta ve modifiye atmosferde muhafazanın kaliteye etkisinin araştırılmasıdır.

Yöntem ve Bulgular: Çalışmada materyal olarak, Hatay ilinde yetiştirilen 'Hicaznar' ve 'Katırbaşı' nar çeşitleri kullanılmıştır. Modifiye atmosferde paketleme (MAP) yapıldıktan sonra meyveler soğuk hava depolarında $6 \pm 0,5$ ? $C^{\prime}$ de ve $\% 90 \pm 5$ oransal nemde 6 ay süreyle depolanmış ve birer aylık aralıklar ile bazı kalite parametrelerinde oluşan değişimler belirlenmiştir. Raf ömrü çalışmaları, 7 gün $20{ }^{\circ} \mathrm{C}$ 'de $\% 75 \pm 5$ oransal koşullarında tutulan meyvelerde gerçekleştirilmiştir. Muhafaza ve raf ömrü sırasında ağırlık kayıpları, MAP ambalajı içindeki $\mathrm{O}_{2}$ ve $\mathrm{CO}_{2}$ konsantrasyonu, meyve kabuk ve tane rengi, görünüş, fungal ve fizyolojik nedenlerle bozulan meyve miktarı ve fizyolojik bozulma şiddeti, usare miktarı, suda çözünebilir toplam kuru madde miktarı, meyve suyu $\mathrm{pH}$ değeri, titre edilebilir asitlik miktarı ve tat değerlerinde oluşan değişimler izlenmiştir.

Genel Yorum: MAP içerisinde muhafaza edilen 'Hicaznar' nar çeşidinin $6^{\circ} \mathrm{C}$ ve $\% 90$ oransal nem koşullarında 4 ay ve 'Katırbaşı' nar çeşidinin ise aynı depolama koşullarında 3 ay süreyle başarıyla depolanabileceği saptanmıştır.

Çalışmanın Önemi ve Etkisi: 'Hicaznar' ve 'Katırbaşı' nar çeşitlerinin soğukta muhafaza sürelerinin belirlenmesine yönelik olarak yürütülen bu çalışmadan elde edilen sonuçların ilgili sektöre, yöreye ve literatüre katkı sunabilecek potansiyele sahip olduğu düşünülmektedir

Anahtar Kelimeler: Nar, 'Hicaznar', 'Katırbaşı', MAP, muhafaza, kalite.

\section{TEŞEKKÜR}

Bu çalışma Hatay Mustafa Kemal Üniversitesi Bilimsel Araştırma Projeleri Komisyonu Başkanlığı tarafından finansal olarak desteklenmiştir (Proje Numarası: 14841). Araştırıcılar 'Hicaznar' nar çeşidi meyvelerinin sağlandığı Hatay Mustafa Kemal Üniversitesi TAUM Müdürlüğüne, 'Katırbaş' nar çeşidi meyvelerinin üretici bahçesinden sağlanmasına katkı sağlayan Zir. Müh. Aliye DiBOĞLU'na, çalışmalar sırasında yardımlarını esirgemeyen Prof. Dr. Elif ÇANDIR'a ve Dr. Öğretim Üyesi Mustafa DiDiN'e, MAP ambalajları iç in Life Pack $^{\circledR} /$ Aypek $^{\circledR}$ MAP ambalaj firmasına, Meriç ÖZKAN ve Prof.Dr. Fatih ŞEN'e desteklerinden dolayı teşekkür etmektedirler.

\section{ÇIKAR ÇATIŞMA BEYANI}

Yazar(lar) çalışma konusunda çıkar çatışmasının olmadığını beyan eder.

\section{ARAŞTIRMACILARIN KATKI ORANI BEYANI}

Yazarlar çalışmaya eşit oranda katkı sağlamış olduklarını beyan eder. 


\section{KAYNAKLAR}

Aksoy MC (2019) Derim sonrası kitosan uygulaması ve modifiye atmosferde paketlemenin 'Hicaznar' nar çeşidinin muhafazasına etkisi. Yüksek Lisans Tezi, Hatay Mustafa Kemal Üniversitesi Fen Bilimleri Enstitüsü, Bahçe Bitkileri Anabilim Dalı, $136 \mathrm{~s}$.

Anonim (2021a) TÜiK Bitkisel Üretim i̇statistikleri. https://biruni.tuik.gov.tr/medas/?kn=92\&locale=tr (Erişim Tarihi: 11 Mayıs 2021)

Anonim (2021b) AKiB Akdeniz ìhracatçı Birlikleri. https://www.akib.org.tr/tr/bilgi-merkezi-sektordegerlendirmeleri-yas-meyve-sebze-ihracatcilaribirligi.html (Erişim Tarihi: 17 Mayıs 2021)

Arendse E, Fawole OA, Opara UL (2014) Influence of storage temperature and duration on postharvest physico-chemical and mechanical properties of pomegranate fruit and arils. CyTA-Journal of Food 12 (4): 389-398.

Arendse E, Fawole OA, Opara UL (2015) Discrimination of pomegranate fruit quality by instrumental and sensory measurements during storage at three temperature regimes. Journal of Food Processing and Preservation 39: 1867-1877.

Artes F, Marin JG, Martinez JA (1996) Controlled atmosphere storage of pomegranate. Z. Lebensm. Unters. Forsch. 203: 33-37.

Artes F, Tudela JA, Gil MI (1998) Improving the keeping quality of pomegranate fruit by intermittent warming. European Food Research and Technology 207: 316-321.

Artes F, Tomas-Barberan FA (2000) Postharvest technological treatmens of pomegranate and preparation of derived products. Departamento de Ciencia Tecnologia de Alimentos CEBAS (CSIC), Murcia, Spain, pp. 199.

Artes F, Tudela JA, Villaescusa R (2000) Thermal postharvest treatments for improving pomegranate quality and shelf life. Postharvest Biol. Technol. 18: 245-251.

Bayram E, Dündar O, Özkaya O (2010) Effect of different packaging types on the cold storage of 'Hicaznar' pomegranate fruits. ISHS Acta Hort. 876: 197-200.

Ben-Arie R, Or E (1986) The development and control of husk scald on 'Wonderful' pomegranate fruit during storage. Journal of the American Society for Horticultural Science 111: 395-399.
Bolel H, Koyuncu MA, Erbaş D (2019) Ozon ve fungusit uygulamalarının narda soğukta depolama boyunca meyve kalitesi değişimi üzerine etkileri. Iğdır Üniversitesi Fen Bilimleri Enstitüsü Dergisi 9(4): 18411850.

Crisosto CH, Mitcham EJ, Kader AA (1996) Fruit produce facts, pomegranate: Recommendations for maintaining postharvest quality. Retrieved May 10, 2021, from http://postharvest.ucdavis.edu/ Commodity_Resources/Fact_Sheets/Datastores/Frui t English/?uid $=53 \& d s=798$.

Çandır E, Özdemir AE, Aksoy MC (2018) Effects of chitosan coating and modified atmosphere packaging on the storage and shelf life of pomegranate fruit cv. 'Hicaznar'. Scientia Horticulturae 235: 235-243.

Çandır E, Özdemir AE, Aksoy MC (2019) Effects of modified atmosphere packaging on the storage and shelf life of 'Hicaznar' pomegranate fruit. Turk. J. Agric. For. 43: 241-253.

Çandır E, Özdemir AE, Göv T, Kanak A, Özçelik H (2020). Minimum işlenmiş 'Katırbaşı' nar çeşidinin soğukta muhafazası. Alatarım 19(1): 9-15.

D’Aquino S, Palma A, Schirra M, Continella A, Tribulato E, La Malfa S (2010) Influence of film wrapping and fludioxonil application on quality of pomegranate fruit. Postharvest Biology and Technology 55: 121128.

Defilippi BG, Whitaker BD, Hess-Pierce BM, Kader AA (2006) Development and control of scald on Wonderful pomegranates during long-term storage. Postharvest Biology and Techn. 41: 234-243.

Elyatem SM, Kader AA (1984) Postharvest physiology and storage behaviour of pomegranate fruits. Scientia Hortic. 24: 287-298.

Farber JN, Harris LJ, Parish ME, Beuchat LR, Suslow TV, Gorney JR, Garrett EH, Busta FF (2003) Microbiological safety of controlled atmosphere and modified atmosphere packaging of fresh and freshcut produce. Comp. Rev. Food Sci. and Food Safety 2: 142-160.

Fawole OA, Opara UL (2013) Effects of storage temperature and duration on physiological responses of pomegranate fruit. Industrial Crops and Products 47: 300-309.

Gil MI, Sanchez R, Marin JG, Artes F (1996) Quality changes in pomegranates during ripening and cold storage. Z. Lebensm. Unters. Forsch. 202: 481-485.

Gil MI, Tomas-Barberan FA, Hess-Pierce B, Holcroft DM, Kader AA (2000) Antioxidant activity of pomegranate juice and its relationship with phenolic composition and processing. Journal of Agricultural and Food Chemistry 48: 4581-4589. 
Gözlekçi S, Erkan M, Karaşahin I, Şahin G (2005) Effect of modified atmosphere packaging (MAP) on the storage of pomegranate fruits (cv. Hicaznar). 9th International Controlled Atmosphere Research Conference Abstracts, July 05-10, Michigan, USA. pp 14.

Heshi AB, Garande VK, Wagh AN, Katore HS (2001) Effect of pre- harvest sprays of chemicals on the quality of pomegranate fruit (Punica granatum L.) cV G-137. Agric. Sci. Digest. 21(1): 25-27.

Kader AA, Chardas A, Elyatem S (1984) Responses of pomegranate to ethylene treatment and storage temperature. Calif. Agr. 38: 14-15.

Karaşahin Z, İş̧imen B, Ünlü M, Baysal Z, Eroğlu EÇ, Özdemir AE (2017) Hicaznar nar çeşidinin soğukta muhafazası üzerine potasyum uygulamalarının etkisi. Meyve Bilimi Özel sayı(1): 78-85.

Kingsly ARP, Singh DB, Manikantan MR, Jain RK (2006) Moisture dependent physical properties of dried pomegranate seeds (Anardana). J. Food Eng. 75: 492496.

Kipri N, Dündar Ö (2011) Derim sonrası sıcak su uygulamasının Hicaznar çeşidinde muhafaza kalitesi üzerine etkisi. Çukurova Üniversitesi Fen ve Mühendislik Bilimleri Dergisi 26(3): 195-204.

Laribi Al, Palou L, Taberner V, Pérez-Gago MB (2012) Modified atmosphere packaging to extend cold storage of pomegranate cv. 'Mollar de Elche'. Retrieved May 11, 2021, from http://www.academia.edu/2500799.

McGuire RG (1992) Reporting of objective colour measurement. HortScience 27: 1254-1255.

Nanda S, Sudhakar Rao DV, Krishnamurthy S (2001). Effects of shrink film wrapping and storage temperature on the shelf life and quality of pomegranate fruits cv. Ganesh. Postharvest Biology and Technology 22: 61-69.

Oğuz Hi, Şen F, Eroğul D (2014) Güneydoğu Anadolu Bölgesinde farklı lokasyonlarda yetiştirilen 'Katırbaşı' nar (Punica granatum L.) çeşidinin depolanma süresince bazı fiziksel ve biyokimyasal içeriklerindeki değişimlerin belirlenmesi. YYÜ Tar. Bil. Derg. 24(3): 309-316.

Onur C (1988) Nar yetiştiriciliği. Derim Dergisi Nar Özel Sayısı 5(4): 147-186.

Onur C, Pekmezci M, Tibet H, Erkan M, Gözlekçi Ş, Tandoğan P (1992) 'Hicaznar'ının soğukta muhafazası üzerinde bir araştırma. Türkiye I. Ulusal Bahçe Bitkileri Kongresi, 13-16 Ekim, İzmir. (1): 449-452.
Onur C, Pekmezci M, Tibet H, Erkan M, Gözlekçi Ş (1995) Nar (Punica granatum L.) muhafazası üzerinde araştırmalar. Türkiye II. Ulusal Bahçe Bitkileri Kongresi, 03-06 Ekim, Adana. (1): 696-700.

Öz AT, Kafkas E, Zarifikhosroshahi M, Şahin T (2015) Hicaznar' çeşidinde farklı uygulamaların soğukta depolama süresince fitokimyasal ve uçucu aroma bileşimine etkileri. Türk Tarım-Gıda Bilim ve Teknoloji Dergisi 3: 235-241.

Palou L, Crisosto CH, Garner D (2007) Combination of postharvest antifungal chemical treatments and controlled atmosphere storage to control gray mold and improve storability of 'Wonderful' pomegranates. Postharvest Biology and Technology 43: 133-142.

Porat R, Kosto I, Daus A (2016) Bulk storage of Wonderful" pomegranate fruit using modified atmosphere bags. Israel Journal of Plant Sciences 63: 45-50.

Rosenblat M, Volkova N, Coleman R, Aviram M (2006) Pomegranate by product administration to apolipoprotein e-deficient mice attenuates atherosclerosis development as a result of decreased macrophage oxidative stress and reduced cellular uptake of oxidized low-density lipoprotein. Journal of Agrıcultural and Food Chemistry 54: 1928-1935.

Sadler GO (1994) Titratable acidity, In: Introduction to the chemical analysis of foods (Ed. Nielsen SS), Jones and Berlett Publishers, Borton, USA, pp 81-91.

Selçuk N, Erkan M (2013) Modifiye atmosferde muhafazanın 'Canernar-1' narlarının antioksidan aktivitesi ve derim sonrası fizyolojisi üzerine etkileri. Akdeniz Üniversitesi Ziraat Fakültesi Dergisi 26(2): 8187.

Selcuk N, Erkan M (2014) Changes in antioxidant activity and postharvest quality of sweet pomegranates $\mathrm{cv}$. Hicrannar under modified atmosphere packaging. Postharvest Biology and Technology 92: 29-36.

Selcuk N Erkan M (2015) Changes in phenolic compounds and antioxidant activity of sour-sweet pomegranates cv. 'Hicaznar' during long-term storage under modified atmosphere packaging. Postharvest Biology and Technology 109: 30-39.

Selcuk N, Erkan M (2016) Impact of passive modified atmosphere packaging on physicochemical properties, bioactive compounds, and quality attributes of sweet pomegranates. Turkish Journal of Agriculture and Forestry 40: 475-488. 
Sezen S (2021). Türkiye ve Dünyadaki nar üretimi, ihracatı ve ithalatı. https://www.hortiturkey.com/yazilar/turkiye-vedunyadaki-nar-uretimi-ihracati-ve-ithalati (Erişim Tarihi: 04 Ağustos 2021).

Şen F, Eroğul D (2012) Adıyaman ilinde yetiştirilen "Hicaznar" nar çesidinin depolama sürecindeki kalite değişiminin belirlenmesi. Süleyman Demirel Üniv. Ziraat Fakültesi Dergisi 7(2): 103-111.

Şen F, Altun A, Kınay Teksür P (2013) Effects of different modified atmosphere packing on storage quality and decay development of 'Hicaznar' pomegranates (Punica granatum L.). Acta Hortic. 1012: 971-978.

Tedford EC, Adaskaveg JE, Ott AJ (2005). Impact of Scholar (a new post-harvest fungicide) on the California pomegranate industry. Plant Health Progress doi:10.1094/PHP-2005-0216-01-PS. Retrieved May 12, 2021, from http://plantmanagementnetwork.org/pub/php/pers pective/2005/scholar
Varasteh F, Arzani K, Barzegar M, Zamani Z (2012) Changes in anthocyanins inarils of chitosan-coated pomegranate (Punica granatum L. cV. Rabbab-eNeyriz) fruit during cold storage. Food Chemistry 130: 267-272.

Yılmaz C (2007). Nar. Hasad Yayıncılık Ltd. Şti., İstanbul. $190 \mathrm{~s}$. 